Jasper De Kind*, Sebastian Dom, Gilles-Maurice de Schryver and Koen Bostoen

\title{
Event-centrality and the pragmatics- semantics interface in Kikongo: From predication focus to progressive aspect and vice versa
}

DOI 10.1515/flih-2015-0005

Abstract: Across Bantu, several polysemic markers expressing progressive aspect and so-called predication focus have been reported (Güldemann 2003; Hyman and Watters 1984). In this article, we examine two such markers in Kikongo (Bantu, H16), i.e. the fronted-infinitive and the locative-infinitive constructions. We provide an in-depth synchronic description of the pragmatic and syntactic behaviour of both verbal constructions and suggest a historical evolution for each of them. We evoke the term 'event-centrality' to cover the different uses of both constructions and suggest that the fronted-infinitive construction's progressive meaning evolved from its use as predication focus marker, and vice versa, that the locative-infinitive construction's predication focus meaning evolved from its use as a progressive marker.

Keywords: event-centrality, predication focus, progressive aspect, fronted-infinitive construction, locative-infinitive construction, Kikongo, Bantu

\section{Introduction}

A polysemy between progressive aspect and so-called predication focus has been reported in several Bantu languages (Güldemann 2003; Hyman and Watters 1984). In this article, we provide an in-depth synchronic and diachronic account of two markers exhibiting this polysemy, i.e. the fronted-infinitive

\footnotetext{
*Corresponding author: Jasper De Kind, KongoKing Research Group, Department of Languages and Cultures, Ghent University, Rozier 44, 9000 Gent, Belgium, E-mail: jasper.dekind@ugent.be Sebastian Dom, KongoKing Research Group, Department of Languages and Cultures, Ghent University, Rozier 44, 9000 Gent, Belgium

Gilles-Maurice de Schryver, KongoKing Research Group, Department of Languages and Cultures, Ghent University, Rozier 44, 9000 Gent, Belgium; University of Pretoria, South Africa Koen Bostoen, KongoKing Research Group, Department of Languages and Cultures, Ghent University, Rozier 44, 9000 Gent, Belgium; Université libre de Bruxelles, Belgium
} 
construction (henceforth FIC) and the locative-infinitive construction (henceforth LOC-INF), which are both particularly prominent in the Kikongo Language Cluster (henceforth KLC). This cluster of closely related language varieties stretches from southern Gabon to northern Angola, including Cabinda, the Lower Congo Province of the Democratic Republic of the Congo (DRC) and the southern part of the Republic of the Congo. It mainly consists of languages from Guthrie's H10 group, but also includes the neighbouring B40 and H30 groups (de Schryver et al. 2015). ${ }^{1}$ This specific language cluster is ideal for a detailed study of microvariation. The KongoKing research group has data of variable quantity and quality for about thirty different present-day Kikongo 'doculects', i.e. Kikongo varieties as they have ended up in the documentation (Bowern 2008: 8; Cysouw and Good 2013: 342). These doculects are sufficiently spread to be representative of the linguistic variation that exists today within the KLC. Moreover, a unique historical corpus, which starts in 1624 with a bilingual Portuguese-Kikongo catechism (Bontinck and Ndembe Nsasi 1978), also enables us to study the potential diachronic processes underlying the synchronic micro-variation. A recent phylogenetic study divided the KLC into four clades, called South, East, West and North, together with a Central contact zone (de Schryver et al. 2015). For each example given in this article, the subgroup is indicated between brackets.

\subsection{The fronted-infinitive construction (FIC)}

The FIC is a verbal construction consisting of a non-finite verb form preceding the same but conjugated verb, as is illustrated in (1) and (2), where the verb stems zawúla and sónika are fronted.

(1) Cizali (west)

Ibúlu zawúla cizawúla.

i-bulu $\emptyset$-zawul-a ci- $\emptyset$-zawul-a

$\mathrm{NP}_{7}$-cattle $\mathrm{NP}_{15}$-run-FV $\mathrm{SC}_{7}$-PRS-run-FV

'The cattle is running.'

(KongoKing fieldwork 2012) $^{2}$

1 Guthrie (1971) used a number of typological and geographical criteria to classify the Bantu languages in different zones indicated by a capital letter (zones A-S) further subdivided in groups indicated by a decimal cipher (10-90). This referential, ahistorical classification is still used by comparative Bantu linguists today because it facilitates the relative geo-location of the Bantu languages.

2 Cf. Addendum A for an overview of the different sources of our Kikongo data, Addendum B for the abbreviations used in the glossing, and Addendum $\mathrm{C}$ for an overview of the terminology used in this article. 
(2) Kimbeko (east)

Sónika káka basónikéni.

$\emptyset$-sonik-a kaka ba- Ø-sonik-idi

$\mathrm{NP}_{15}$-write-FV only $\mathrm{SC}_{2}$-PRS-write-PRF

'They only wrote (a report).'

(KongoKing fieldwork 2012)

The FIC is widespread among West Bantu languages of Guthrie's zones B and H (Hadermann 1996), but has also been reported elsewhere, for instance in the South-Western Bantu language Thimbukushu (K333) (Güldemann 2003: 336) and in the East Bantu languages Sifwe (K402) (Hilde Gunnink p.c.) and Kikuyu (E51) (Morimoto 2014). Meeussen (1967) reconstructs this common periphrasis to Proto-Bantu, calling it the 'advance verb construction':

A peculiar kind of sentence, with twice the same verb, the first occurrence being an infinitive, is attested frequently, and will have to be ascribed to Proto-Bantu. The meaning varies between stress of « reality », stress of « degree », and even « concession » : kutákuna báátákunide, « they chewed as (much as) they could »; " (as for chewing) they did chew, (but ...) ». (Meeussen 1967: 121)

In this article we examine the different uses of the FIC within the KLC and show that the FIC is not only used to express progressive aspect as in (1) and predication focus as in (2), as previously reported (Güldemann 2003: 335-337; Hadermann 1996), but has also become a future marker in some Kikongo varieties, as shown for Kindibu in (3).

(3) Kindibu (central)

ye matoko meno mona memona mbona zameso

ye ma-toko ma-eno $\emptyset$-mon-a me- $\emptyset$-mon-a N-mona

and $\mathrm{NP}_{6}$-youngster $\mathrm{PP}_{6}$-POSS 2 pl $\mathrm{NP}_{15}$-see-FV $\mathrm{SC}_{6}$-PRS-See-FV $\mathrm{NP}_{10}$-vision

za ma-iso

$\mathrm{CONN}_{10} \mathrm{NP}_{6}$-eye

'and your youth will see visions'

(New Testament 1923: Acts 2, 17)

\subsection{The locative-infinitive construction (LOC-INF)}

The LOC-INF construction is a complex verb construction consisting of the auxiliary 'to be' and the locative marker $m u$ followed by the infinitive. The Loc-INF constituent either follows the auxiliary, as in (4), where mu vova is preceded by the Aux kena, or is preposed, as in (5), where mu sauka precedes bena.

3 Focus in the English translation is marked by using bold typeface. 
(4) Kindibu (central)

Ye vana vau va kena mu vova diaka koko dia nsusu dikokwele.

ye vana vau va-ka- $\varnothing$-in-a mu $\emptyset$-vov-a diaka $\varnothing$-koko

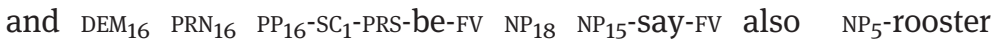

dia N-susu di- $\varnothing$-kokul-idi

$\mathrm{CONN}_{5} \mathrm{NP}_{9}$-chicken $\mathrm{SC}_{5}$-PRS-crow-PRF

'Immediately, while he was still speaking, a rooster crowed.'

(New Testament 1923: Luke 22, 60)

(5) Kisikongo (south)

Tala! Aneyisaele mu sauka bena o Nkoko a Yodani.

tal-a a-neyisaele mu $\emptyset$-sauk-a ba- $\varnothing$-in-a o-N-koko

look-FV $\quad \mathrm{NP}_{2}$-israelite $\quad \mathrm{NP}_{18} \quad \mathrm{NP}_{15}$-cross-FV $\quad \mathrm{SC}_{2}$-PRs-be-FV $\mathrm{AUG}_{3}$ - $\mathrm{NP}_{3}$-river

a yodani

conN Jordan

'Look! The Israelites are crossing the Jordan River.'

(JW's Tusansu 2013: 103)

The LOC-INF construction also exhibits polysemy between progressive aspect and predication focus, as we will show in this article.

\subsection{Structure of this article}

The different functions of both the FIC and the LOC-INF constructions are discussed in Sections 2 and 3 respectively. We provide new empirical evidence, using data from previously unexplored historical Kikongo texts (mainly religious material), complemented with data reported in Kikongo grammars as well as with new elicited data obtained through fieldwork with native speakers in both the DRC and the diaspora in Belgium. The elicitation of data on Information Structure (IS) was based on the Questionnaire on Information Structure (QUIS) (Skopeteas et al. 2006). In Section 4, we provide a historical-linguistic account of the polysemy attested by both constructions. Conclusions are presented in Section 5.

\section{The fronted-infinitive construction}

The FIC is a verbal construction consisting of a non-finite verb form preceding the same conjugated verb. The term 'non-finite' is more appropriate here than 
'infinitive' for certain Kikongo varieties. As the examples (1) to (3) illustrate, the preposed verb form is lacking the common Bantu infinitive noun prefix $\mathrm{ku}$-, which is a reflex of Proto-Bantu ${ }^{\star} k \grave{\text { - }}$ (Schadeberg 2003: 149). In several Kikongo varieties, prefix-less infinitives are regular, due to a common process of prefix reduction that also affected the infinitive noun class prefix (Bostoen and de Schryver 2015). Consequently, the forms in (1) and (3) could still be considered infinitives. However, in eastern varieties such as Kimbeko in (2), the noun prefix of the infinitive is not systematically dropped outside the FIc. Hence, the preposed verb form could be interpreted as a verb stem rather than as an infinitive, not only in Kimbeko (2), but also in Cizali (1) and Kindibu (3). Nevertheless, in a limited number of Kikongo varieties, such as Kisundi in (6) or Civili in (7), the noun prefix $k u$ - is observed in the FIc. It therefore seems as if this prefix was originally part of the FIC and the label 'fronted-infinitive' can be maintained.

(6) Kisundi (north)

kusola lwetisola

ku-sol-a lu-eti-sol-a

$\mathrm{NP}_{15}$-cultivate-FV $\mathrm{SC}_{2 \mathrm{pl}}$-PROG-cultivate-FV

'you are cultivating'

(N’landu Kitambika 1994: 146)

The syntactic cohesion between the main verb and the fronted infinitive is not absolute in that certain constituents can be inserted between both, such as an adverb, as káká in (2), or even the lexical subject, such as ńcદ́tù, 'woman' in the Civili example in (7).

(7) Civili (west)

Ńcćtù ùábúlà Piele? Kó kútélà ńcétù ùàntélà.

ń-cćtù ù-á-búl-à piele ko kú-tél-à ń-cétù

$\mathrm{NP}_{1}$-woman $\mathrm{SC}_{1}$-PRF-beat-FV Pierre no $\mathrm{NP}_{15}$-call-FV $\mathrm{NP}_{1}$-woman

ù-à-ń-tél-à

$\mathrm{SC}_{1}$-PRF-OC 1 -call-Fv

'Has the woman beaten Pierre? No, the woman has (only) called him.' (Ndouli 2012: 5)

\subsection{Predication focus (PCF)}

The FIC can be considered to be a marker of what Dik (1997: 326) calls 'focal information': 
The focal information in a linguistic expression is that information which is relatively the most important or salient in the given communicative setting, and considered by $\mathrm{S}$ [peaker] to be the most essential for $\mathrm{A}$ [ddressee] to integrate into his pragmatic information. The focal information will thus concern the changes that S[peaker] wishes to bring about in the pragmatic information of A[ddressee]. Such changes may take different forms: S[peaker] may wish to add pieces of information to A[ddressee]'s pragmatic information, or he may wish to replace some piece of information $\mathrm{X}$ which he assumes $\mathrm{A}$ [ddressee] possesses by some piece of information $\mathrm{Y}$ which he possesses himself.

The primordial function of the FIC is then to convey 'predication focus' (henceforth PCF) as defined by Güldemann (2003: 330-331), i.e. focus centred on the predicate, but excluding objects and adjuncts. This is not to be confounded with Lambrecht's (1994: 226) 'predicate focus', which is broader in scope and targets the whole verb phrase including the object and/or adjunct, if present. Predicate focus is "the universally unmarked type of focus structure" (Van Valin and LaPolla 1997: 206), whereby the predicate phrase expresses a comment about the topic represented by the subject. Güldemann's PCF is narrower in that it centres either on the verb lexeme or on a predication operator linked with the verb expressing values such as polarity, truth, time, aspect, or modality. In terms of focus locus, it is comparable to 'term focus' (Güldemann 2003: 330) or 'argument focus' (Lambrecht 1994: 228ff), which targets specific nominal and adverbial clause constituents.

In Kikongo, the FIC can be used to express focus on the lexical meaning of the verb, also called State-of-Affairs or SoA focus (Güldemann 2010). In (2) and (7) above, as well as in (8) and (9) below, the speaker wishes to replace pragmatic information in the hearer's mind by contrastively focusing the verb lexeme.

(8) Kisolongo (south)

a. Yántu nwána benwánánga?

ya-ntu $\emptyset$-nwan-a be- $\emptyset$-nwan-ang-a $\mathrm{NP}_{2}$-person $\mathrm{NP}_{15}$-fight-Fv $\mathrm{SC}_{2}$-PRs-fight-IPFV-FV

'Are the people fighting?'

b. Pé, kebenwánánga ko, kína bekínánga.

pe ke-be- $\emptyset$-nwan-ang-a ko $\emptyset$-kin-a be- $\emptyset$-kin-ang-a

no NEG-SC2 2 -PRS-fight-IPFV-FV NEG $\mathrm{NP}_{15}$-dance-Fv SC2$_{2}$-PRS-dance-IPFV-FV

'No, they're not fighting, they're dancing.'

(KongoKing fieldwork 2012) 
(9) Southern Kikongo proverb ${ }^{4}$

Tata kafwa ko. Fubwa kafubwa.

tata ka-a-fw-a ko Ø-fub-u-a ka-a-fub-u-a

father NEG.SC 1 -PST-die-FV NEG NP 15 -burn-PASS-FV SC SC $_{1}$-PST-burn-PASS-FV

'The father didn't die, he was burnt.'

(António n.d.: 53)

'Contrastive focus', also known as identification focus, on the verb lexeme, as illustrated in (2), (7), (8) and (9) above, is to be distinguished from 'assertive focus' or '(new) information focus', highlighting pragmatic information which the speaker wishes to add to the hearer's knowledge (Kiss 1998). In (10) below, the verb's lexical meaning 'to cut' represents the new information, given as an answer to the question and highlighted by means of the FIc. In this marked assertive verb focus construction, the given information, i.e. ntí 'tree', is given less prominence as it is represented by the postverbal resumptive pronoun wáo.

(10) Ciwoyo (west)

a. Ncyá kátubízi basalíz'u ntí?

ncya ka- $\emptyset$-tub-izi ba- $\emptyset$-sal-il-izi u-N-ti

what $\mathrm{SC}_{1}$-PST-Say-PFV $\mathrm{SC}_{2}$-PST-do-APPL-PFV $\mathrm{AUG}_{3}$-NP3 - -tree

'What did she say that they did to the tree?'

b. Zénga bazengéza wáo.

$\emptyset$-zeng-a ba- $\emptyset$-zeng-eza wao

$\mathrm{NP}_{15}$-Cut-Fv $\mathrm{SC}_{2}$-PRS-Cut-PFV $\mathrm{PRN}_{3}$

'They cut it.'

(KongoKing fieldwork 2012)

It is more difficult to conceive marked assertive focus on predication operators. They rarely represent new information added to the hearer's knowledge. They rather tend to be contrastively focused. A FIC may indeed also convey contrastive 'truth focus' pertaining to the clause's positive truth value, as opposed to its negated counterpart (Güldemann 2003: 330). In the English translation, this is often rendered by the emphatic adverb 'surely', as in (11). In other Bible translations, we find different emphatic adverbs, such as claramente in Spanish, heel goed in Dutch, and wohl in German. In (12), the truth value is lexically strengthened by the noun e ziku 'certainty', which is used here adverbially.

4 The proverbs collected in António's work do not pertain to one specific Kikongo variety but could be considered a mixture of several southern Kikongo varieties, such as Kizombo, Kisikongo, Kindamba and Kitsotso. 
(11) Kindibu (central)

Mona mbwene nkenda za zula kiame kina muna Egipto.

$\emptyset$-mon-a N- $\varnothing$-mon-idi N-kenda za $\emptyset$-zula

$\mathrm{NP}_{15}$-see-FV $\mathrm{SC}_{1 \mathrm{SG}}$-PRS-See-PRF $\mathrm{NP}_{10}$-affliction $\mathrm{CONN}_{10} \quad \mathrm{NP}_{7}$-people

ki-ame kina muna egipto

$\mathrm{PP}_{7}-\mathrm{POSS}_{1 \mathrm{SG}} \quad \mathrm{DEM}_{7} \quad \mathrm{DEM}_{18} \quad$ Egypt

'I have surely seen the affliction of that people of mine there in Egypt.'

(New Testament 1923: Acts 7, 34)

(12) Kisikongo (south)

Akuluntu, zaya bazeye wo e ziku vo yandi i Kristu e?

a-kuluntu $\emptyset$-zay-a ba- $\varnothing$-zay-idi wo e ziku vo

$\mathrm{NP}_{2}$-leader $\mathrm{NP}_{15}$-know-FV $\mathrm{SC}_{2}$-PRs-know-PRF $\mathrm{PRN}_{3}$ AUG9 certainty that

yandi i kristu e

$\mathrm{PRN}_{1}$ be Christ $\mathrm{Q}$

'Can it be that the rulers indeed know that this is truly the Christ?'

(New Testament 1926: John 7, 26)

The verbs tanga 'read/handle' and langidila 'protect' in (13) could also be considered instances of truth value focus. Rather than focusing on the verb lexeme, the FIC marks the importance of the fact that the actions are definitely being carried out, as opposed to its negative counterpart of not being carried out.

(13) Kisikongo (south)

O mambu mama twasisilua mo.

o-ma-ambu mama tu-a-sis-il-u-a mo

$\mathrm{AUG}_{6}-\mathrm{NP}_{6}$-matter $\mathrm{DEM}_{6} \quad \mathrm{SC}_{1 \mathrm{PL}}$-PST-leave-APPL-PASS-FV PRN $_{6}$

'These problems that they left us.'

Literally: 'These problems, we were left with them.'

O mambu mama tanga tutanga mo.

o-ma-ambu mama tang-a tu- $\varnothing$-tang-a mo

$\mathrm{AUG}_{6}-\mathrm{NP}_{6}$-matter $\mathrm{DEM}_{6}$ read-FV $\mathrm{SC}_{1 \mathrm{PL}}$-FUT-read-FV $\mathrm{PRN}_{6}$

'These problems, we will handle them.'

O lualuolumbu langidila tulangidilanga $l o$.

o-lwalu o-lu-mbu langidil-a tu- $\emptyset$-langidil-ang-a lo

$\mathrm{AUG}_{11}$ - $\mathrm{DEM}_{11} \quad \mathrm{AUG}_{11}-\mathrm{NP}_{11}$-enclosure protect-FV $\mathrm{SC}_{1 \mathrm{PL}}$-PRS-protect-IPFV-FV $\mathrm{PRN}_{11}$

'We are protecting our area.'

Literally: 'This enclosure, we are protecting it.'

(IB fieldwork Mbanza Kongo 2003) 
The focused operator may also be a TAM marker, although it is not so easy to find clear-cut cases of this type of PCF in our corpus. The sentences in (14) and (15) could qualify as such examples, but they are not unambiguous. In (14), the speaker, i.e. Jesus, stresses that he goes on working in imitation of his father. The contrastive topic at the beginning of the second part of the sentence, marked by the emphatic marker mpe (Bentley 1887: 354), is followed by a FIC which repeats and doubles the earlier mentioned verb -sala 'to work'. The lexical content of the verb being given, the focus conveyed by the FIC could be interpreted as rather pertaining here to the continuous aspect of the action. In (15), the FIC could also be read as highlighting the verb's aspect. Due to the imminence of the Lord's coming, speaking is no longer possible. An event-central thetic interpretation (cf. infra), however, is not excluded either, since the FIC serves as an explanation for the preceding utterance. In this case, the postposed subject nkuluntu a nza yayi is to be considered less important than the event expressed by the verb.

(14) Kisikongo (south)

O S’ame osalanga yamu wau,

o- $\varnothing$-se ame o- $\varnothing$-sal-ang-a yamu wau

$\mathrm{AUG}_{1}-\mathrm{NP}_{1}$-father POSS $_{1 \mathrm{SG}} \mathrm{SC}_{1}$-PRS-work-IPFV-FV until $\mathrm{PRN}_{14}$

'My father is still working,

omono mpe sala nsalanga.

o-mono mpe $\varnothing$-sal-a N- $\varnothing$-sal-ang-a

$\mathrm{AUG}_{1}-\mathrm{PRN}_{1 \mathrm{SG}}$ also $\mathrm{NP}_{15}$-work-FV $\mathrm{SC}_{1 \mathrm{SG}}$-PRS-work-IPFV-FV

(so) me too I keep on working.'

(JW's Fimpanga 2013: 47)

(15) Kisikongo (south)

Kivova yeno diaka mengi ko,

ki- $\emptyset$-vov-a yeno diaka ma-ingi ko

NEG.SC ${ }_{1 \mathrm{SG}}$-FUT-speak-FV PRN $_{2 \mathrm{SG}}$ also $\mathrm{NP}_{6}$-much NEG

'I will no more speak much with you,

kadi kwiza kekwiz’o nkuluntu a nza yayi.

kadi ku-iz-a ke- Ø-ku-iz-a o-N-kuluntu a

because $\mathrm{NP}_{15}$-come-FV $\mathrm{SC}_{1}$-PRS- $\mathrm{NP}_{15}$-Come-FV $\mathrm{AUG}_{1}-\mathrm{NP}_{1}$-leader CONN

$\mathrm{N}-\mathrm{za} \quad$ yayi

$\mathrm{NP}_{9}$-world DEM9

for the ruler of this world is coming.'

(New Testament 1926: John 14, 30) 
All these different subtypes of PCF have in common that they put focus on some aspect of the verb, or in other words, on the event (which is expressed by the verb). However, the FIC is not only used to express these different types of PCF as defined by Güldemann (2003), i.e. verb focus and focus on a predication operator. In our Kikongo text corpus, the FIC also occurs outside such a clearly defined PCF context. What all these other attestations have in common with the PCF functions, though, is exactly this 'event-central' function. The utterance is centred around the event expressed by the verb. To describe and to account for these alternative uses of the FIC, first a distinction between categorical and thetic sentences should be made. As Sasse (1987) defines it:

The thetic statement forms a unit with respect to what it contributes to the discourse at a given point. It expresses a pragmatically unanalyzed state of affairs and presents it as a piece of complex information [...]. This is not the case with the categorical statement. It presents a state of affairs as something analyzed, dissected into different information units. It selects one of the participants of the state of affairs in order to present it as a predication base and arranges the rest in such a way that it forms the predication about the selected predication base. (Sasse 1987: 558)

In other words, categorical sentences refer to those sentences with a typical topic-comment structure, while thetic sentences lack such an internal information structure. Remarkably, the FIC has only been attested in event-central categorical sentences, and not in the so-called 'event-central thetic utterances', as defined by Sasse (1987: 526-527). Consider the categorical sentences in (16) and (17) below, where neither the verb lexeme nor a predication operator is under the scope of narrow focus, neither contrastively nor assertively as in replying to a $\mathrm{WH}$-question.

(16) Kisikongo (south)

E nkumbu sobwa isobelo.

e-N-kumbu $\quad$-sob-u-a i- $\varnothing$-sob-idi-u

$\mathrm{AUG}_{9}$-NP9-name $\mathrm{NP}_{15}$-change-PASS-FV $\mathrm{SC}_{9}$-PRS-change-PRF-PASS

'The name has been changed.'

(JW's Mbumba 2013: 155)

(17) Kimanyanga (central)

Bukazeyi vo kota kakotele.

bu-ka- $\emptyset$-zay-idi vo $\emptyset$-kot-a ka-a-kot-idi

$\mathrm{PP}_{14}$-SC $\mathrm{S}_{1}$-PRS-know-PRF that $\mathrm{NP}_{15}$-enter-FV $\mathrm{SC}_{1}$-PST-enter-PRF

'When he knows that he had entered.'

(Matuka 1991: 133) 
In both sentences, the subject refers to an earlier-mentioned constituent. Example (16) is a footnote to the sentence 'In 1988, an Italian woman named Lucia was very depressed', while the subject as $3^{\text {rd }}$ person singular in (17) is already mentioned in the first part of the sentence. Both subjects can thus be considered the topic of the utterance, while the verb constitutes the comment. As was mentioned earlier, a topic-comment utterance has been termed 'predicate focus' by Lambrecht (1994: 226) and is considered to be the unmarked focus structure in the sense of being the most normal utterance type in discourse. When this comment includes an object, as in (18), or an adjunct, such as mu nzo in (19) and mu maza in (20), a FIC is unattested. However, when the verb solely constitutes the comment, as in (16) and (17), a FIC does occur. The FIC is then used as a formal means to express unmarked focus in an event-central comment.

(18) Ciwoyo (west)

Mvítá bizóla.

$\mathrm{N}$-vita ba-i-zol-a

$\mathrm{NP}_{9}$-war $\mathrm{SC}_{2}$-PRS-want-FV

'They want war.'

(KongoKing fieldwork 2012)

(19) Kindibu (central)

Ebosi una kasindikidi e ndonga, wizidi mu nzo.

ebosi una ka- $\emptyset$-sindik-idi e-N-donga u- $\emptyset$-iz-idi

then $\mathrm{DEM}_{14} \quad \mathrm{SC}_{1}$-PRS-send.away-PRF $\quad \mathrm{AUG}_{9}$-NP9-people $\mathrm{SC}_{1}$-PRS-go-PRF

$\mathrm{mu} \quad \mathrm{N}-\mathrm{zO}$

LOC $_{18} \mathrm{NP}_{9}$-house

'Then he sent the people away and went into the house.'

(New Testament 1923: Matthew 13, 36)

(20) Southern Kikongo proverb

Nzonzi mu maza kaleka, mu maza kalambilwanga.

N-zonzi mu ma-aza ka-Ø-lek-a mu ma-aza

$\mathrm{NP}_{9}$-fish $\quad \mathrm{LOC}_{18} \quad \mathrm{NP}_{6}$-water $\quad \mathrm{SC}_{1}$-PRS-sleep-FV $\quad$ LOC $_{18} \quad \mathrm{NP}_{6}$-water

ka-Ø-lamb-il-u-ang-a

$\mathrm{SC}_{1}$-PRS-cook-APPL-PASS-IPFV-FV

'The fish sleeps (lives) in the water, and is cooked in the water.'

(António n.d.: 145)

Event-central thetic utterances have not been found in association with a FIC. Following Sasse (1987: 566), some prototypical examples of theticity include 
weather expressions (21) and explanations without presupposed subjects (22)-(23).

(21) Kisikongo (south)

Mvula yinokene.

N-vula yi- $\emptyset$-nok-idi

$\mathrm{NP}_{9}$-rain $\mathrm{SC}_{9}$-PRS-rain-PRF

'It has rained.'

(JDK fieldwork Antwerp 2013)

(22) Ciwoyo (west)

Nzyó yábwà.

$\mathrm{N}-\mathrm{zo} \quad \mathrm{i}-\mathrm{a}-\mathrm{bw}-\mathrm{a}$

$\mathrm{NP}_{9}$-house $\mathrm{SC}_{9}$-PST-fall-FV

[What happened?] 'The house collapsed.'

(KongoKing fieldwork 2012)

(23) Kisikongo (south)

Ekuma? Ekuma kadi wantu awonso basumuka.

e- $\varnothing$-kuma e- $\varnothing$-kuma kadi wa-ntu a-onso

$\mathrm{AUG}_{7}-\mathrm{NP}_{7}$-reason $\mathrm{AUG}_{7}-\mathrm{NP}_{7}$-reason because $\mathrm{NP}_{2}$-person $\mathrm{PP}_{2}$-every

ba- Ø-sumuk-a

$\mathrm{SC}_{2}$-PRS-Sin-FV

'Why? Because all humans sin.'

(JW's Tusansu 2013: 207)

Compare these examples with the explanatory categorical sentences in (24), (25) and (26), in which a FIC can be used. These examples differ from the previous ones in the presuppositionality of the subject: presupposed subjects are expressed in categorical sentences (in a topic-comment structure), while nonpresupposed subjects are expressed in thetic sentences (Sasse 1996: 37).

(24) Kisikongo (south)

E fulumwinu kiandi una se kivaika (kadi fwa kafwidi).

e- $\varnothing$-fulumwinu ki-andi una se ki-vaik-a kadi

$\mathrm{AUG}_{7}-\mathrm{NP}_{7}$-respiration $\mathrm{PP}_{7}$-POSS 1 $\mathrm{DEM}_{14}$ then $\mathrm{SC}_{7}$-go.out-FV because

$\emptyset$-fw-a ka- $\emptyset$-fw-idi

$\mathrm{NP}_{15}$-die-FV $\mathrm{SC}_{1}$-PRS-die-PRF

'Her soul was going out at that moment (because she died).'

(Old Testament 1916: Genesis 35, 18) 
(25) Kisikongo (south)

Alongoki ke bamvutula ko,

a-longoki ke ba-N- $\varnothing$-vutul-a ko

$\mathrm{NP}_{2}$-student $\mathrm{NEG} \quad \mathrm{SC}_{2}$-OC $\mathrm{O}_{1}$-PRS-answer-FV NEG

'The apostles don't answer him,

kadi tantana batantananga muna nzila [...]

kadi Ø-tantan-a ba-a-tantan-ang-a muna N-zila

because $\mathrm{NP}_{15}$-argue-FV $\mathrm{SC}_{2}$-PST-argue-IPFV-FV $\quad \mathrm{DEM}_{18} \quad \mathrm{NP}_{9}$-road

because on the road they were arguing [...]'

(JW's Tusansu 2013: 207)

(26) Fiote (central)

kadi vova luvovanga mu mpamba

kadi $\emptyset$-vov-a lu- $\varnothing$-vov-ang-a mu N-pamba

because $\mathrm{NP}_{15}$-Speak-FV $\mathrm{SC}_{2 \mathrm{PL}}$-PRS-Speak-IPFV-FV LOC $_{18} \quad \mathrm{NP}_{9}$-vanity

'because you are speaking in the air'

(New Testament 1929: 1 Corinthians 14, 9)

One could argue that example (15) above is also an event-central thetic expression, since the FIC serves as an explanation for the preceding utterance, and the subject is apparently non-presupposed. However, this example constitutes the only candidate for an event-central thetic function of the FIC and is therefore not strong evidence for this claim, especially since no other evidence has been found in the data so far.

The role of event-centrality can also be observed in Descourvières' Kakongo grammar from the late eighteenth century, as copied by Cuénot (1776). Although it is not clear whether these examples should be considered categorical sentences with a topic-comment structure, or 'out-of-the blue' thetic utterances, it is clear that a FIC appears when no object is present, as in (27) and (28), while the presence of an object correlates with the absence of the FIc, as in (29) and (30).

(27) Kakongo (west)

bela u li bela

$\emptyset$-bel-a u-li-bel-a

$\mathrm{NP}_{15}$-be.sick-FV $\mathrm{SC}_{2 \mathrm{SG}}$-PRs-be.sick-FV

'you are sick'

(Cuénot 1776: 19 verso) 
(28) Kakongo (west)

lia u li lia

$\emptyset$-li-a u-li-li-a

$\mathrm{NP}_{15}$-eat-Fv $\mathrm{SC}_{2 \mathrm{SG}}$-PRS-eat-FV

'you eat/are eating'

(Cuénot 1776: 19 recto)

(29) Kakongo (west)

fu u li lia

$\emptyset$-fu u-li-li-a

$\mathrm{NP}_{10}$-fish $\mathrm{SC}_{2 \mathrm{SG}}$-PRs-eat-FV

'you eat/are eating fish'

(Cuénot 1776: 19 recto)

(30) Kakongo (west)

u ma même ma li lia i b'titi

u-ma-meme ma-li-li-a i-bi-titi

$\mathrm{AUG}_{6}$ - $\mathrm{NP}_{6}$-Sheep $\mathrm{SC}_{6}$-PRS-eat-Fv $\mathrm{AUG}_{8}$ - $\mathrm{NP}_{8}$-grass

'the sheep eat/are eating grass'

(Cuénot 1776: 19 verso)

\subsection{Progressivity}

The FIC has been reported to also convey progressivity in some Kikongo varieties (Güldemann 2003; Hadermann 1996). The clearest instance which Hadermann (1996: 161) provides of this aspect-marking function of the FIC is the example in (31) from Le Ussel (1888: 43), who describes the West Kikongo variety formerly called Fiote and known today as Civili. As shown in (7) above, the FIC can be used in present-day Civili to express contrastive verb focus. In (31), it would rather express a 'neutral' progressive sentence without focus on the verb 'to work', as opposed to the example in (32), where the simple verb would express a non-progressive present. This tense-aspect is marked here by the morpheme $n$-. According to Hadermann (1996: 161), this present tense marker grammaticalized from the LOC-INF construction, also treated in this article. Parallel with the phonological attrition of 'AUX $m u k u$-INF' to ' $n$-STEM', its meaning would have lost its progressive aspect to become a punctual present. 
(31) Civili (west)

minu kusala insala

minu ku-sal-a i-n-sal-a

PRN $_{1 \mathrm{SG}} \quad \mathrm{NP}_{15}$-work-FV $\quad \mathrm{SC}_{1 \mathrm{sG}}$-PRS-work-FV

'moi, je suis en train de travailler'

'me, I am working'

(Le Ussel 1888: 43)

(32) Civili (west)

minu insala

minu i-n-sal-a

$\mathrm{PRN}_{1 \mathrm{SG}} \quad \mathrm{SC}_{1 \mathrm{SG}}$-PRS-work-FV

'moi, je travaille'

'me, I work'

(Le Ussel 1888: 43)

In several other Kikongo varieties, similar examples have been found. However, most of these examples consist of intransitive clauses lacking an adjunct, as in (1), (6) and (16) above, and (33) and (34) below. Consequently, they can equally be explained as marking event-centrality, as argued above.

(33) Kisikongo (south)

kadi samba kesamba

kadi $\emptyset$-samb-a ke- $\emptyset$-samb-a

but $\mathrm{NP}_{15}$-pray-FV $\quad \mathrm{SC}_{1}$-PRs-pray-FV

'(but) he is praying'

(New Testament 1926: Acts 9, 12)

(34) Ciwoyo (west)

Vwáta kivwáta.

$\emptyset$-vwat-a ka-i-vwat-a

$\mathrm{NP}_{15}$-dress-FV SC $_{1}$-PRs-dress-FV

'He's dressing up.'

(KongoKing fieldwork 2012)

This ambiguity between a PCF and a progressive reading ties in with the close semantic/pragmatic relation that has been observed between both categories in Bantu and elsewhere (Güldemann 2003; Hyman and Watters 1984). Güldemann (2003: 346ff) considers the progressive to be an "inherently focused verb category", in which the ongoing nature of the event described by the verb is the most important information and thus constitutes the focus domain of the utterance. 
The examples in (1), (6), (16) and (33) do not provide hard evidence to consider the FIC as a fully developed marker of progressivity, as Hadermann (1996: 161) claims to be the case in example (31) above from nineteenth century Civili. Instead of having become fully semanticized as an independent meaning, it could rather be considered as an instantiation derived from its use as verb focus marker, i.e. a case of 'pragmatic inference' as discussed in Evans (2003: 20-23). A specific reading becomes depragmaticized when it is used outside the original pragmatic context in which it surfaced. It is only then that true polysemy emerges. The progressive reading of the FIC is rarely observed outside the pragmatic context of verb focus. The primacy of its use as verb focus marker is especially straightforward in those Fics where the main verb carries a dedicated progressive marker, such as -eti- in the Kisundi example in (6). This suggests that the FIC is not the progressive marker an sich.

Instances of a FIC expressing progressivity outside the pragmatic context of PCF are rare. Examples such as (35), (36), (37) and (38) are rather the exception than the rule. No other progressive marker is present here and the FIC is followed by an object and/or adjunct, which excludes an event-central focus reading. Nevertheless, as we will argue in Section 4.2, the FIC still cannot be considered a fully developed progressive marker since it is incompatible with negation and preverbal argument focus.

(35) Iwoyo (west)

Befo liya tiliya madezo.

befo $\emptyset$-li-a tu-i-li-a ma-dezo

$\mathrm{PRN}_{1 \mathrm{PL}} \quad \mathrm{NP}_{15}$-eat-FV $\quad \mathrm{SC}_{1 \mathrm{PL}}$-PRS-eat-FV NP $\mathrm{NP}_{6}$-bean

'We're eating beans.'

(Mingas 1994: 334)

(36) Kindibu (central)

Ovo vitila keluvitila ku ntu ku Galilea.

ovo Ø-vit-il-a ke-lu- $\emptyset$-vit-il-a $\quad \mathrm{ku} \quad \mathrm{N}$-tu $\mathrm{ku}$ galilea

$\mathrm{DEM}_{16} \quad \mathrm{NP}_{15}$-go-APPL-FV SC $\mathrm{SC}_{1}-\mathrm{OC}_{2 \mathrm{PL}}$-PRS-go-APPL-FV LOC 17 NP3 -head LOC ${ }_{17}$ Galilea

'He is leading you the way to Galilea.'

(New Testament 1923: Mark 16, 7)

(37) Nzebi (B52)

Bàkà:sé bán'á:, vádá bâavádá péndà.

ba-kase bana $\emptyset$-vad-a ba- $\emptyset$-vad-a $\emptyset$-penda

$\mathrm{NP}_{2}$-woman $\mathrm{DEM}_{2} \quad \mathrm{NP}_{15}$-cultivate-Fv $\mathrm{SC}_{2}$-PRS-cultivate-Fv NP 10 -peanut

'These women are growing peanuts.'

(Marchal-Nasse 1989, cited in Hadermann 1996: 162) 
(38) Ciwoyo (west)

Vúúka kivúúka sámu yóbala.

$\emptyset$-vuuk-a ka-i-vuuk-a

samu Ø-yobal-a

$\mathrm{NP}_{15}$-undress-FV $\mathrm{SC}_{1}$-PRS-undress-FV to $\quad \mathrm{NP}_{15}$-wash(intr.)-FV

'He's undressing to wash.'

(KongoKing fieldwork 2012)

\subsection{Future}

In a limited number of Kikongo varieties, the FIC is also observed in association with the future tense. This seems to be most common in Kindibu, as shown in (3) above and (39) below.

(39) Kindibu (central)

ye kwiza tukwiza kwa yandi

ye ku-iz-a tu- Ø-ku-iz-a kwa yandi

and $\mathrm{NP}_{15}$-come-FV $\quad \mathrm{SC}_{1 \mathrm{PL}}$-PRS-NP 15 -Come-FV $\mathrm{CONN}_{17} \quad \mathrm{PRN}_{1}$

'and we will come to him'

(New Testament 1923: John 14, 23)

Also in Kisikongo such examples of a future meaning in correlation with a FIC are attested, as shown in (40) and (41).

(40) Kisikongo (south)

kansi kwiza nkwiza kwa yeno

kansi ku-iz-a N-Ø-ku-iz-a kwa yeno

but $\quad \mathrm{NP}_{15}$-come-FV $\quad \mathrm{SC}_{1 \mathrm{SG}}$-FUT-NP 15 -Come-FV CONN $_{17} \quad \mathrm{PRN}_{2 \mathrm{PL}}$

'but I will come to you'

(New Testament 1926: 1 Corinthians 16, 5)

(41) Kisikongo (south)

kwiza tukwiza vana kena

ku-iz-a tu- $\varnothing-k u-i z-a \quad$ vana ka-in-a

$\mathrm{NP}_{15}$-come-FV $\mathrm{SC}_{1 \mathrm{PL}}$-FUT-NP 15 -Come-FV $\quad \mathrm{DEM}_{16} \quad \mathrm{SC}_{1}$-be-FV

'we will come to him'

(New Testament 1926: John 14, 23)

In all the examples of a future-correlated FIC presented here, the verb is followed by either an object, as in (3), or an adjunct, as in (39), (40) and (41), indicating that 
the future meaning also surfaces outside the typical pragmatic context of PCF. The future possibly developed from the progressive reading of the FIC rather than directly from its use as PCF marker. Present progressives, and presents more generally, often become (near) futures in both Bantu and languages elsewhere (Bastin 1989; Nurse 2008: 118). If the FIC did indeed develop a tertiary future meaning out of its secondary progressive meaning in certain Kikongo varieties, this new meaning became more strongly semanticized than its source. As a future marker it seems to have gained a greater independence from the FIc's privileged PCF contexts than as a progressive marker. However, it is important to note that the simple zero-tense-marked verb also developed future time reference in the South Kikongo varieties Kisolongo, Kisikongo and Kizombo (Dom and Bostoen 2015) as well as in Kindibu (Coene 1960: 11). It can therefore not be excluded that the FIc became future-correlated through analogy with the non-doubled base verb. Further research needs to be done on this topic.

Our polylectal Kikongo corpus has not revealed the future FIC for other varieties. However, certain Kikongo grammars do suggest that the FIC is also used as future marker in Kizombo (42) and Kitsotso (43), both spoken in the southern part of the KLC. Interestingly, in contrast to what happened in other South Kikongo varieties including Kizombo, the simple zero-tense-marked verb did not develop future time reference in Kitsotso (Baka 1992; Dom and Bostoen 2015). This could indicate that here, the FIC acquired its future meaning independently from the non-doubled base verb. Unfortunately, the reported examples in both Kizombo and Kitsotso lack a proper context to determine a possible PCF function, but an event-central focus reading is not excluded, since in both cases the FIC is part of an intransitive clause in which the comment is only constituted by the verb.

(42) Kizombo (south)

Sosa tusosa.

$\emptyset$-sos-a tu- $\emptyset$-sos-a

$\mathrm{NP}_{15}$-search-FV SC $_{1 \mathrm{PL}}$-FUT-search-FV

'We'll search (tomorrow).'

(Mpanzu 1994: 136)

(43) Kitsotso (south)

Kwiza kakwiza.

ku-iz-a ka- Ø-ku-iz-a

$\mathrm{NP}_{15}$-come-FV SC SCPRS-NP $_{15}$-come-Fv

'He'll arrive (tomorrow).'

(Baka 1992: 110) 
A future reading has also been observed in Kiyaka (H33), a so-called Kikongoid language (de Schryver et al. 2015) situated in the extreme east of the KLC. Here as well, a proper context is missing to allow for an appropriate pragmatic interpretation.

(44) Kiyaka (H33)

(vuumbuka) yivuumbuka

$\emptyset$-vuumbuk-a yi- $\emptyset$-vuumbuk-a

$\mathrm{NP}_{15}$-dress-FV $\quad \mathrm{SC}_{1 \mathrm{SG}}$-PRS-dress-FV

'I'll dress myself'

(Van Den Eynde 1968: 47)

The examples (42)-(44) taken from grammars are not very satisfying, but in combination with the corpus examples in (3) and (39)-(41) they indicate that the future meaning of the FIC occurs specifically in the southern and south-eastern part of the KLC, as well as in Kiyaka spoken to its east.

\section{The locative-infinitive construction}

In its basic form, the LOC-INF construction consists of an auxiliary 'to be' and the locative prefix $m u$ - followed by an infinitive verb form. As discussed above, two main word orders are attested: AUX LOC-INF (4) and its inverted counterpart LOC-INF Aux (5). The locative marker is the noun prefix of class 18 reconstructed in ProtoBantu as ${ }^{*} m \dot{\text { - }}$, which indicates primarily the state of being within or inside somewhere (Grégoire 1975). In Kikongo, mu also refers first and foremost to a place in, a rest in or a motion inside of or out from something (Bentley 1887: 115; Laman 1912: 154). The LOC-INF construction thus basically denotes the fact of being in the midst of doing something (Hadermann 1996: 160).

Reduced forms of the LOC-INF construction are attested throughout the KLC. A common reduction is the suppression of the entire auxiliary, as in (45).

(45) Kiyombe (west)

Mu kota mu nzo, lukùnda yo.

mu Ø-kot-a mu N-zo, lu- Ø-kund-a yo

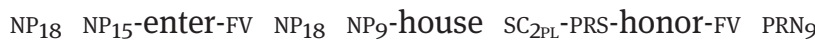

'As you enter into the household, greet it.'

(New Testament 1920: Matthew 10, 12)

Through univerbation and subsequent fusion of its different components, this periphrasis possibly further evolved to even more reduced verb forms in which 
the original locative prefix $m u$ - has become a simple tense marker. As discussed above, Hadermann (1996: 161) considers the present tense marker $n$ - in nineteenth century Civili in (32) as the outcome of such a grammaticalization. It would be the phonologically reduced remnant of the locative prefix mu-. The same present tense marker is attested in closely related Kiyombe (De Clercq 1921: 36), as shown in (46), where it co-exists with the less reduced LOC-INF construction illustrated in (45).

(46) Kiyombe (west)

Yez'unkembe : "Minu kuandi wuwu, ndinsosa yaku. "

yezu u-N-Ø-kamb-idi minu kwandi wuwu ndi-n-sos-a

Jesus $\mathrm{SC}_{1}$-OC $\mathrm{OC}_{1}$-PRS-Say-PRF $\mathrm{PRN}_{1 \mathrm{SG}} \quad \mathrm{FM} \quad \mathrm{DEM}_{1} \quad \mathrm{SC}_{1 \mathrm{SG}}$-PRS-Speak-FV

ye aku

with POSS $_{2 \mathrm{sG}}$

'Jesus said to her, "It is me the one who speaks to you."'

(New Testament 1920: John 4, 26)

The non-reduced form of the locative prefix $m u$ - is possibly observed in the Kikamba example in (47), where it marks, in combination with - $a$-, the present progressive. This is possibly the outcome of a different grammaticalization of the LOC-INF construction.

(47) Kikamba (north)

Nàmùsálà

N-a-mu-sal-a

$\mathrm{SC}_{1 \mathrm{sG}}$-PRS-PROG-work-FV

'I am working'

(Bouka 1989: Section 4.321.114)

The grammaticalization of the LOC-INF construction into different verb conjugations needs more research. In this article, however, we are primarily concerned with its semantics.

\subsection{Progressivity}

Within the KLC, the LOC-INF construction serves first and foremost to express progressive aspect. As demonstrated by Bastin (1989), this is the predominant function of this construction throughout Bantu, where she observed it in Guthrie's zones B, C, D, H, K, L, M, N, and P. Across the KLC, the LOC-INF 
construction is significantly more frequent as a progressive marker than as a PCF marker. It has been found expressing both present progressive, as in (5) and (45) above, and past progressive, as in (4) above, and (48), (49) and (50) below. This meaning is observed both with the AUX LOC-INF order, as in (4), (48) and (50), and with the inverted LOC-INF AUX order, as in (5) and (49), and even in the absence of the auxiliary, as in (45). This indicates that the progressive meaning is firmly rooted in the LOC-INF construction, and that it is certainly not a case of pragmatic inference as with the FIC.

(48) Kimanyanga (central)

Bu kakala mu yela kua mfuilu wazingila beni va ntanda.

bu-ka-a-kal-a mu Ø-yel-a kwa N-fwilu u-a-zingil-a

$\mathrm{PP}_{14}$-SC $\mathrm{SC}_{1}$-PST-be-FV $\quad \mathrm{NP}_{18} \quad \mathrm{NP}_{15}$-be.ill-FV $\quad \mathrm{CONN}_{15} \quad \mathrm{NP}_{9}$-death $\mathrm{SC}_{1}$-PST-Stay-FV

beni va $\mathrm{N}$-tanda

much $\mathrm{NP}_{16} \quad \mathrm{NP}_{3}$-bed

'When he was sick to death, he lay for a long time in his bed.'

(ms. Laman c. 1915, in MacGaffey 2000: 191)

(49) Kindibu (central)

Wau una wantu mu leka bena, mbeni andi wizidi.

wau una wa-ntu mu Ø-lek-a ba-a-in-a

$\mathrm{DEM}_{14} \quad \mathrm{DEM}_{14} \quad \mathrm{NP}_{2}$-person $\quad \mathrm{NP}_{18} \quad \mathrm{NP}_{15}$-sleep-FV $\quad \mathrm{SC}_{2}$-PST-be-FV

$\mathrm{N}$-beni andi $\mathrm{u}-\varnothing$-iz-idi

$\mathrm{NP}_{3}$-enemy $\mathrm{POSS}_{1} \quad \mathrm{SC}_{1}$-PRS-come-PRF

'While the people were sleeping, his enemy came.'

(New Testament 1923: Matthew 13, 25)

(50) Kintandu (east)

Bukakala mu goga diaka, kibuka kisidi.

bu-ka- $\emptyset$-kal-a mu $\emptyset$-gog-a diaka ki-buka ki- $\emptyset$-sal-idi

$\mathrm{PP}_{14}$-SC $\mathrm{SC}_{1}$-PST-be-FV $\quad \mathrm{NP}_{18} \quad \mathrm{NP}_{15}$-Say-FV also $\mathrm{SC}_{7}$-crowd $\mathrm{SC}_{7}$-PST-remain-PRF

'When he was still speaking, a crowd remained.'

(New Testament 1956: Luke 22, 47)

A particularly interesting example from Kindibu is given in (51). It illustrates the semantic distribution of three different markers: the imperfective suffix -ang-, the LOC-INF and the FIC. In this example, the LOC-INF conveys a past progressive

5 Cf. Addendum A for more information on this source. 
('were eating'), which can also be expressed by the pre-final marker -ang- (in 'they sat/were sitting'). The FIC yekola kekunyekola serves here as a marker of truth value focus, strengthened lexically by kieleka 'really; truly'. The second -ang- marks a present progressive, hinting at Judas who is eating with Jesus. ${ }^{6}$

(51) Kindibu (central)

Ye una bafonganga ku meza

ye una ba-a-fong-ang-a $\mathrm{ku}$ meza

and DEM $_{14} \quad \mathrm{SC}_{2}$-PST-Sit-IPFV-FV $\quad \mathrm{NP}_{17} \quad \mathrm{NP}_{6}$.table

'As they sat at the table

ye mu dia bena, Yezo uvovele:

ye mu $\emptyset$-di-a ba- $\emptyset$-in-a yezo $u$ - $\emptyset$-vov-idi

and $\mathrm{NP}_{18} \quad \mathrm{NP}_{15}$-eat-FV $\mathrm{SC}_{2}$-PRs-be-FV Jesus $\mathrm{SC}_{1}$-PRS-Speak-PRF

and were eating, Jesus said,

kieleka ikuluvova vo mosi vana vena yeno

ki-eleka i-ku-lu- $\emptyset$-vov-a vo mosi vana

$\mathrm{NP}_{7}$-truth $\mathrm{SC}_{1 \mathrm{SG}}$-EXPL-OC $2 \mathrm{PL}$-PRS-Speak-FV $\mathrm{PRN}_{16}$ one $\mathrm{DEM}_{16}$

va- $\varnothing$-in-a yeno

$\mathrm{PP}_{16}$-PRS-be-FV PRN $_{2 \mathrm{PL}}$

"Most assuredly I tell you, one of you

yekola kekunyekola, yandi udianga yame.

$\emptyset$-yekol-a ke-ku-N- $\varnothing$-yekol-a yandi u- $\emptyset$-di-ang-a

$\mathrm{NP}_{15}$-betray-FV $\quad \mathrm{SC}_{1}$-EXPL-OC ${ }_{1 \mathrm{SG}}$-PRs-betray-FV $\quad \mathrm{PRN}_{1} \quad \mathrm{SC}_{1}$-PRS-eat-IPFV-FV

ye ame

with POSS $_{1 \mathrm{sG}}$

will betray me - he who is eating with me."

(New Testament 1923: Mark 14, 18)

The association between the LOC-INF and progressivity in Kikongo goes back at least 400 years, since it is observed in the diachronic example in (52), taken from the oldest Kikongo text available, i.e. the 1624 bilingual Portuguese-Kikongo catechism (Cardoso 1624). The Kikongo used here is the South Kikongo variety spoken at that time in the capital of the Kongo kingdom.

6 Being a general imperfective marker, -ang- could also mark a habitual, denoting that Judas eats regularly with Jesus. Given the context 'sitting at the table', we interpret it here as a present progressive, but a habitual reading is not excluded. 
(52) South Kikongo of four centuries ago Akatuiidi e mionyo miaa asantu massee a-Ø-katul-idi e-mi-onyo mia a-santu ma-se $\mathrm{SC}_{1}$-PRS-deliver-PRF $\quad \mathrm{AUG}_{4}-\mathrm{NP}_{4}$-Soul $\mathrm{CONN}_{4} \quad \mathrm{NP}_{2}$-Saint $\mathrm{NP}_{6}$-father 'That he may deliver the souls of the Saint Fathers miaaikeete kunaa mu kukinga o luizu luandi lua ukissi. mi- $\emptyset$-akal-idi kuna mu ku-king-a o-lu-izu lu-andi $\mathrm{PP}_{4}$-PRS-be-PRF $\quad \mathrm{DEM}_{17} \quad \mathrm{NP}_{18} \quad \mathrm{NP}_{15}$-wait-FV $\mathrm{AUG}_{11}$ - $\mathrm{NP}_{11}$-coming $\mathrm{PP}_{11}$ - $\mathrm{POSS}_{1}$ lwa u-kisi $\mathrm{CONN}_{11} \mathrm{NP}_{14}$-charm who are awaiting there his holy coming.' (Cardoso 1624, in Bontinck and Ndembe Nsasi 1978: 116)

\subsection{Predication focus and event-central theticity}

The polysemy between predication focus and progressivity observed for the FIC is also attested with the Loc-INF, even though the latter is much less common as PCF marker across the KLC. Instances of LOC-INF signalling PCF have so far only been observed in Kintandu, the main East Kikongo variety.

The Kintandu Bible passage in (53) contains a series of such Loc-INF, all highlighting the truth value of the actions expressed. In this case, the Loc-INF serves as a confirmation of a given command.

(53) Kintandu (east)

Ye go ntele ku yu: nda wenda!, mu kwenda,

ye go N-Ø-tel-idi $\mathrm{ku}$ yu nda $\mathrm{u}$ - $\emptyset$-end-a mu ku-end-a

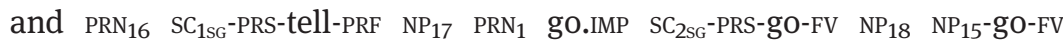
'And if I tell this one: "You go!", he goes;

ku yu unkaka: nza!, mu kwisa, $\mathrm{ku}$ yu unkaka nza mu ku-is-a $\mathrm{NP}_{17} \mathrm{PRN}_{1}$ other come.IMP $\mathrm{NP}_{18} \quad \mathrm{NP}_{15}$-come-Fv to another, "Come!", he comes;

ye ku nleke amo: sala ma!, mu sala.

ye $\mathrm{ku}$ N-leke amo sal-a ma mu Ø-sal-a and $\mathrm{NP}_{17} \quad \mathrm{NP}_{1}$-boy $\mathrm{POSS}_{1 \mathrm{sg}}$ do-FV $\mathrm{PRN}_{6} \quad \mathrm{NP}_{18} \mathrm{NP}_{15}$-do-FV and to my servant, "Do this", he does it.' (New Testament 1956: Luke 7, 8) 
Interestingly enough, as illustrated in (54), the FIC is used in the Kindibu translation of the same Bible passage. This highlights the pragmatic relation between the FIC and the LOC-INF in signalling PCF.

(54) Kindibu (central)

Ye mvova kwa oyu vo wenda ye kwenda kekwenda;

ye $\mathrm{N}$ - $\emptyset$-vov-a kwa o-yu vo u- $\emptyset$-end-a

and $\mathrm{SC}_{1 \mathrm{SG}}$-PRS-Say-FV $\mathrm{CONN}_{17} \quad \mathrm{AUG}_{1}-\mathrm{PRN}_{1} \quad \mathrm{PRN}_{16} \quad \mathrm{SC}_{2 \mathrm{SG}}$-PRS-go-FV

ye ku-end-a ke- $\varnothing$-ku-end-a

and $\mathrm{NP}_{15}$-go-FV $\mathrm{SC}_{1}$-PRS-NP${ }_{15}$-go-FV

'And if I tell this one: "You go!", he goes;

kwa ankaka vo wiza, ye kwiza kekwiza;

kwa ankaka vo u-Ø-iz-a ye ku-iz-a

$\mathrm{CONN}_{17}$ another $\mathrm{PRN}_{16} \quad \mathrm{SC}_{2 \mathrm{SG}}$-PRS-Come-FV and $\mathrm{NP}_{15}$-Come-FV

ke- Ø-ku-iz-a

$\mathrm{SC}_{1}$-PRS-NP 15 -come-FV

to another, "You come!", he comes;

ye kwa nleke ame, vanga wo, ye vanga kevanga.

ye kwa N-leke ame vang-a wo ye $\emptyset$-vang-a ke- $\emptyset$-vang-a and $\mathrm{CONN}_{17} \mathrm{NP}_{1}$-slave $\mathrm{POSS}_{1 \mathrm{sG}}$ do-FV $\mathrm{DEM}_{3}$ and $\mathrm{NP}_{15}$-do-FV $\mathrm{SC}_{1}$-PRS-do-FV and to my servant, "Do this", he does it.'

(New Testament 1923: Luke 7, 8)

In the so-called Fiote translation of the same Bible passage - not to be confounded with the Fiote referring to the nineteenth century Civili (cf. supra) - yet another strategy is used to convey the same focus type, i.e. the locative possessive pronoun kwandi (class 17). This is actually a more general focus marker, which is also used in other Kikongo varieties to signal argument focus.

(55) Fiote (central)

Mpovele kwa mosi: Wenda, wele kwandi;

$\mathrm{N}$ - $\emptyset$-vov-idi kwa mosi u- $\emptyset$-end-a u- $\emptyset$-end-idi ku-andi

$\mathrm{SC}_{1 \mathrm{SG}}$-PRS-Say-PRF $\mathrm{CONN}_{17}$ one $\mathrm{SC}_{2 \mathrm{SG}}$-PRS-go-FV $\mathrm{SC}_{1}$-PRS-go-PRF $\mathrm{PP}_{17}$-POSS 1

'If I tell this one: "You go!”, he goes;

kwa wankaka: Wiza, wizidi kwandi;

kwa wankaka u- Ø-iz-a u- Ø-iz-idi ku-andi

$\mathrm{CONN}_{17}$ another $\mathrm{SC}_{2 \mathrm{SG}}$-PRS-Come-FV $\quad \mathrm{SC}_{1}$-PRS-Come-PRF $\mathrm{PP}_{17}$-POSS $_{1}$

to another, "You come!", he comes; 
kwa nang'ami: Vanga kiaki, vengi kio kwandi.

kwa nanga ami vang-a kiaki $\emptyset$ - -vang-idi kio ku-andi

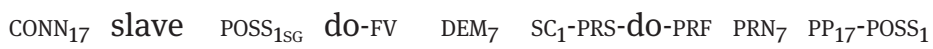

to my servant, "Do this", he does it.'

(New Testament 1929: Luke 7, 8)

One should note that neither in Kindibu nor in Fiote the respective PCF-signalling strategies combine with progressive tense marking, which suggests that the use of the LOC-INF in Kintandu to signal PCF happens independently from the construction's basic progressive meaning.

Another example from Kintandu is given in (56), in which the most logical interpretation seems to be an event-central thetic one. The new information includes both subjects and predicates in this series of LOC-INF constructions:

(56) Kintandu (east)

Buna vutwele ku bau nde : "Lwenda

buna $\emptyset$ - $\emptyset$-vutul-idi $\quad \mathrm{ku}$ bau nde lu-end-a

DEM $_{14} \quad \mathrm{SC}_{1}$-PRS-answer-PRF $\quad \mathrm{NP}_{17} \quad \mathrm{PRN}_{2}$ QUOT $\quad \mathrm{SC}_{2 \mathrm{PL}}$-gO-FV

'He answered them, "Go

samuna ku Jean ma lumwene ye ma luwidi:

$\emptyset$-samun-a ku jean ma lu- $\emptyset$-mon-idi ye ma lu- $\emptyset$-u-idi

$\mathrm{NP}_{15}$-tell-FV $\quad \mathrm{NP}_{17}$ John $\mathrm{PRN}_{6} \quad \mathrm{SC}_{2 \mathrm{PL}}$-PRS-see-PRF and $\mathrm{PRN}_{6} \quad \mathrm{SC}_{2 \mathrm{PL}}$-PRS-hear-PRF

and tell John the things which you have seen and heard:

bifwa-meso mu mona,

bi-fwa ma-iso mu Ø-mon-a

$\mathrm{NP}_{8}$-death $\mathrm{NP}_{6}$-eye $\mathrm{NP}_{18} \quad \mathrm{NP}_{15}$-See-Fv

the blind receive their sight,

bifwa-malu mu diata,

bi-fwa ma-alu mu ø-diat-a, $\mathrm{NP}_{8}$-death $\quad \mathrm{NP}_{6}$-leg $\quad \mathrm{NP}_{18} \quad \mathrm{NP}_{15}$-walk-Fv

the lame walk,

bankwa-nzambi mu beluka,

ba-nkwa N-zambi mu Ø-beluk-a

$\mathrm{NP}_{2}$-leper $\quad \mathrm{NP}_{9}$-god $\quad \mathrm{NP}_{18} \quad \mathrm{NP}_{15}$-heal-Fv

the lepers are cleansed, 
bifwa-makutu mu wa,

bi-fwa ma-kutu mu $\boldsymbol{\emptyset}$-u-a

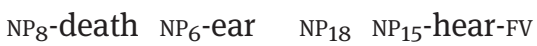

the deaf hear,

ba bafwa mu futumuka,

ba ba-fwa mu Ø-futumuk-a

$\begin{array}{llll}\mathrm{DEM}_{2} & \mathrm{NP}_{2} \text {-dead } & \mathrm{NP}_{18} & \mathrm{NP}_{15} \text {-stand.up-FV }\end{array}$

the dead rise,

bamputu mu wa bena Nsangu zimbote. "

ba-mputu mu $\boldsymbol{\emptyset}$-u-a ba- $\varnothing$-in-a N-sangu zi N-bote

$\mathrm{NP}_{2}$-poor $\quad \mathrm{NP}_{18} \quad \mathrm{NP}_{15}$-hear-FV $\quad \mathrm{SC}_{2}$-PRS-be-FV $\quad \mathrm{NP}_{10}$-news $\quad \mathrm{CNN}_{10} \quad \mathrm{NP}_{9}$-goodness

the poor have good news preached to them."'

(New Testament 1956: Luke 7, 22)

\section{From PCF to progressivity and vice versa}

Although predication focus and progressive aspect belong to two different functional domains, i.e. pragmatics and semantics respectively, many markers across Bantu concurrently fulfil both functions (Güldemann 2003; Hyman and Watters 1984). The FIC and the LOC-INF are but two of the markers displaying this kind of polysemy. Following Hyman and Watters (1984), Güldemann (2003: 350) considers the progressive to be an inherently focused verb category:

I venture that the progressive is a verb category with inherent focus [...]. It is viewed here as an AMALGAMATION between the semantic property of the represented state of affairs, i.e. its aspectual feature of, mostly dynamic, imperfectivity, and the focus of the utterance. Within the above definition frame of the focus domain it can be said that the continuous, ongoing nature of an event is that information which is viewed by the speaker to be the most relevant for the addressee in a given communicative context. (emphasis in original $)^{7}$

7 In this citation, 'the above definition frame of the focus domain' corresponds to a combination of Dik's (1997: 326) definition of focal information in a linguistic expression: "that information which is relatively the most important or salient in the given communicative setting, and considered by S[peaker] to be the most essential for A[ddressee] to integrate into his pragmatic information”, and the development of the PCF concept as outlined in Section 2.1 above. 
In other words, the inherent semantics of a progressive as expressing the ongoing nature of an event is the most important information of the utterance and consequently constitutes the focus domain of that utterance. Cross-linguistically, Güldemann (2003: 347) observes several cases in which a progressive evolved out of a predication focus function. Moreover, he also presents cross-linguistic evidence showing that the progressive belongs to "the focused set of verb grams" (Güldemann 2003: 348, paraphrasing Hyman and Watters 1984: 263). An extra argument in this regard is the existence of languages in which progressives are incompatible with other types of focus:

[...] progressive grams of some languages are impossible in contexts where the information peak of the utterance excludes the predicate, such as term focus constructions, content questions, background clauses, and sentences with what Horn (1989) has called 'metalinguistic negation'. Such a situation is reported by Gottschligg (p.c. and 1992: 153 [...]) for the majority of Ful varieties (Atlantic, Niger-Congo). Kiefer (1994: 189-190, 196) might give evidence for a similar phenomenon in Hungarian (Finno-Ugric, Uralic) when mentioning that the progressive is excluded from term focus constructions. (Güldemann 2003: 348)

This final argument, however, appears cyclical if we consider PCF markers as original sources for progressive markers. It seems obvious that whenever a progressive evolved out of a PCF marker, the latter still influences to some degree the behaviour of the former. Güldemann (2003: 344) acknowledges this by evoking the phenomenon of 'persistence' (Hopper 1991: 28-30).

In the following sections we will examine more closely the historical relation between PCF and progressivity in Kikongo for both the FIC and the LOC-INF. We will consider several criteria to determine the directionality of the change from one function to the other.

\subsection{Formal features of a focus construction}

\subsubsection{Word order}

The most obvious characteristic, which the FIC shares with other focus constructions in Kikongo, is the preverbal position of the infinitive. The default place for argument focus in Kikongo is also in front of the verb. A narrowly focused argument or adjunct is usually fronted, as shown in (57) where the preverbal object is under assertive focus. This example would be an appropriate answer to a question such as 'What did the chief kill?'. 
(57) Ciwoyo (west)

Mfyumú ngo kavondéza. ${ }^{8}$

$\mathrm{N}$-fumu N-go ka- $\emptyset$-vond-eza

$\mathrm{NP}_{9}$-chief $\mathrm{NP}_{9}$-leopard $\mathrm{SC}_{1}$-PROX-kill-PFV

'The chief killed a leopard.'

(KongoKing fieldwork 2012)

Contrastively focused arguments are also rendered preverbally, as in (58).

(58) Kisolongo (south)

Mphúku kaka mphóndeléénge.

$\mathrm{N}$-puku kaka N-Ø-vond-idiingi

$\mathrm{NP}_{9}$-rat only $\mathrm{SC}_{1 \mathrm{sG}}$-PROX-kill-PFV

'I've only killed a rat.'

(KongoKing fieldwork 2012)

In the same vein, the FIC could be considered as a "preposed focus constituent in the form of a nominal term and the following finite verb is the predicate" (Güldemann 2003: 335). The Ciwoyo sentence in (59b), which is an answer to the question in (59a), illustrates how a contrastively focused infinitive can be preposed to the main verb, as a focused object would be.

(59) Ciwoyo (west)

a. Wéndéza sáli?

wa- $\varnothing$-end-eza $\varnothing$-sal-a i

$\mathrm{SC}_{1}$-PROX-go-PFV NP 15 -work-FV Q

'Did he go to work?'

b. Vé, kuténtha kendéza.

ve ku-tenth-a ka- Ø-end-eza

no $\mathrm{NP}_{15}$-sleep-FV $\mathrm{SC}_{1}$-PRS-go-PFV

'No, he (only) went to sleep.'

c. Vé, téntha kendéza téntha.

ve $\emptyset$-tenth-a ka- $\varnothing$-end-eza $\emptyset$-tenth-a

no $\mathrm{NP}_{15}$-sleep-FV $\mathrm{SC}_{1}$-PROX-go-PFV $\mathrm{NP}_{15}$-sleep-FV

'No, he (only) went to sleep.'

(KongoKing fieldwork 2012)

8 Ciwoyo nouns belonging to class 5 and 7 do not display an overt noun prefix. For these nouns the first consonant of the noun stem is regularly followed by a palatal glide. Such palatal diphthongization also occurs with the non-syllabic nasal of class 9 and $\mathrm{SC}_{1 \mathrm{sg}}$, as in nzyó, mfyumú and ngyó in (22), (57) = (61), and (60), but less regularly. Palatalization is only noted when realized as such by our language consultants. 
An alternative answer to the same question is presented in (59c). This is a true FIC in which the verb -téntha 'to sleep' functions as the main verb rather than as complement and in which -enda 'to go' is an auxiliary rather than a main verb (contrary to (59b), in which -enda is considered to be the main verb, lexically expressing 'going to'). A possible analysis - which however requires further research - is that the preposed infinitive in (59b) could be considered as an example of argument focus, in which the infinitive functions as a focused noun, while in (59c) a FIC signals focus on the verb, i.e. signalling PCF focus rather than argument focus. This shows that, although structurally related, the FIC is clearly distinct from an object-preposing construction signalling argument focus. In Ciwoyo, this also seems to have repercussions on the surface representation of the infinitive's $k u$ - prefix, which is absent in the FIC (59c), but present in the other pre-posing construction (59b).

As pointed out above, the LOC-INF construction frequently displays word order inversion in that the LOC-INF may both precede and follow the auxiliary 'to be'. However, these inversions (i.e. LOC-INF AUx) do not seem to be pragmatically conditioned, since they also occur in Kikongo varieties where the LOC-INF construction has no obvious focus-related function. Even in varieties where the LOC-INF may express PCF, instances are observed where the LOC-INF AUX order purely involves the expression of progressivity, which is unmistakably the construction's primary function. However, the proposal, if true, that the progressive is somehow an inherently focused verb category may still have contributed to the generalization of the LOC-INF AUX order. Since the LOC-INF component covers the most salient information within the construction, it naturally precedes the less salient auxiliary, which is even often dropped all together. Moreover, the evolution of inverted word orders, such as SOV (vs. SVO), to become pragmatically unmarked is a wider Kikongo phenomenon which needs more in-depth study (Bearth 2003: 135; De Kind 2014).

\subsubsection{Morphological focus marking}

Another characteristic feature of both constructions is the use of one specific subject marker for the 3sg/class 1, i.e. $k a-$. This verbal prefix stands in an allomorphic relation with a set of other prefixes and is used, among others, whenever an inversion takes place and a postverbal argument is moved to the preverbal domain. This allomorphy is not restricted to Kikongo, as it has also been observed in other western Bantu languages, such as Mbuun (B87) (Bostoen and Mundeke 2012). As illustrated in (57) and (58), such an inversion is used to convey argument focus. Compare (60), in which SVO order correlates with the 
use of $\mathrm{SC}_{1}$ wa-, with (57), repeated in (61), where SOV order correlates with object focus and the use of $\mathrm{SC}_{1} k a-$.

(60) Ciwoyo (west)

Mfumú wávóndézi ngyó.

$\mathrm{N}$-fumu wa- $\emptyset$-vond-eza i-N-go

$\mathrm{NP}_{9}$-chief $\mathrm{SC}_{1}$-PROX-kill-PFV AUG9-NP9-leopard

'The chief killed a leopard.'

(KongoKing fieldwork 2012)

(61) Ciwoyo (west)

Mfyumú ngo kavondéza.

$\mathrm{N}$-fumu N-go ka- $\varnothing$-vond-eza

$\mathrm{NP}_{9}$-chief $\mathrm{NP}_{9}$-leopard $\mathrm{SC}_{1}$-PROX-kill-PFV

'The chief killed a leopard.'

(KongoKing fieldwork 2012)

The same alternation is observed when one contrasts a regular auxiliary construction, as in (62), with a FIC, as in (63). Note that both the adverb tóka and the auxiliary intervene here between the two components of the redoubled main verb.

(62) Ciwoyo (west)

Wéndeza nwána?

wa-a-end-eza Ø-nwan-a

$\mathrm{SC}_{1}$-DIST-gO-PFV $\mathrm{NP}_{15}$-fight-FV

'Did he go fighting?'

(KongoKing fieldwork 2012)

(63) Ciwoyo (west)

Vé, túba tóka kendéza tuba.

ve Ø-tub-a toka ka-a-end-eza Ø-tub-a

no $\mathrm{NP}_{15}$-talk-FV only $\mathrm{SC}_{1}$-DIST-go-PFV $\mathrm{NP}_{15}$-talk-FV

'No, he only went talking.'

(KongoKing fieldwork 2012)

The same allomorphy, finally, is observed with LOC-INF constructions, when one opposes AUX LOC-INF, as in (64), to LOC-INF AUX, as in (65). The $k a$ - prefix only surfaces when the LOC-INF component is preposed, which suggests that the latter LOC-INF type is indeed a focus construction, at least in origin. Note that example (64) illustrates the use of the LOC-INF as a near future marker (nFUT) as well. 
(64) Kintandu (east)

Welemuka kuna ntwala, mete muna nti sikomore

u-?-Ø-lemuk-a kuna N-twala $\emptyset$ - $\varnothing$-mat-idi muna N-ti

$\begin{array}{llllll}\mathrm{SC}_{1} \text {-?-PST-run-FV } & \mathrm{DEM}_{17} & \mathrm{NP}_{9} \text {-needle } & \mathrm{SC}_{1} \text {-PRS-climb-PRF } & \mathrm{DEM}_{18} & \mathrm{NP}_{3} \text {-tree }\end{array}$

sikomore

sycamore

'He ran on ahead, and climbed up into a sycamore tree

mu mona Yezu, yu ukala mu luta kûna.

mu Ø-mon-a yezu yu u-

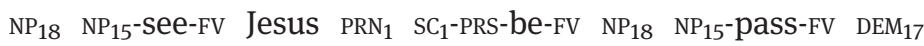

to see Jesus, for he was to pass that way.'

(New Testament 1956: Luke 19, 4)

(65) Kintandu (east)

Ba bata samuna nde: (Yezu) mu zinga kena.

ba ba-ta-samun-a nde yezu mu Ø-zing-a ka- $\emptyset$-in-a

$\mathrm{DEM}_{2} \quad \mathrm{SC}_{2}$-PROG-tell-FV that Jesus $\mathrm{NP}_{18} \quad \mathrm{NP}_{15}$-live-FV $\mathrm{SC}_{1}$-PRS-be-FV

'These are telling that Jesus is alive.'

(New Testament 1956: Luke 24, 23)

\subsection{Incompatibility with other focus contexts}

The phenomenon known as 'persistence' (Hopper 1991: 28-30), whereby grammaticalized or grammaticalizing markers tend to maintain certain features of their original sources, is also relevant here. In the case of progressive markers originally expressing PCF this implies widespread incompatibility with background clauses, negative contexts and other focus types, such as argument focus (Güldemann 2003: 344). ${ }^{9}$

\subsubsection{Negation}

The FIC is indeed incompatible with negation in Kikongo, as illustrated in (66). Negating the FIC seen in (66a) as shown in (66c) is ungrammatical. It can only be negated as in (66b). The same applies to the Ciwoyo example in (67).

9 Negation and PCF are semantically speaking not incompatible, since negation itself can be considered as marking focus on the (negative) truth-value of the negated verb. This seems to be exactly the reason why these two competing PCF strategies are mutually incompatible. 
(66) Kimanyanga (central)

a. Lúta betilúta.

$\emptyset$-lut-a ba-eti-lut-a

$\mathrm{NP}_{15}$-pass-FV SC $_{2}$-PROG-pass-FV

'They are passing.'

b. Báu kabetilúta ko.

bau ka-ba-eti-lut-a ko

$\mathrm{PRN}_{2}$ NEG-SC 2 -PROG-pass-FV NEG

'They are not passing.'

c. ${ }^{*}$ Bau luta kabetiluta ko.

Intended: 'They are not passing.'

(JDK fieldwork Brussels 2013)

(67) Ciwoyo (west)

a. Lyá kilyá.

Ø-li-a ka-i-li-a

$\mathrm{NP}_{15}$-eat-FV SC $\mathrm{S}_{1}$-PRS-eat-FV

'He's eating.'

b. Nandí kisílya kó.

Nandi ka-i-si-li-a ko

$\mathrm{PRN}_{1} \quad \mathrm{SC}_{1}$-PRS-NEG-eat-FV NEG

'He's not eating.'

(KongoKing fieldwork 2012)

Similarly, in the Kindibu example in (68), a FIC is used outside the negative clause to express progressivity. A PCF reading is excluded here, since the subject is focused. In the same Bible passage in Kisikongo, the verb is part of the negative clause and does not occur as a FIc, even if this is the construction one would expect in Kisikongo to convey progressivity, especially in an intransitive clause as the one in (69).

(68) Kindibu (central)

Kadi yeno ke yeno ko vova luvova.

kadi yeno ke yeno ko Ø-vov-a lu- $\varnothing$-vov-a

for $\mathrm{PRN}_{2 \mathrm{PL}}$ NEG $\mathrm{PRN}_{2 \mathrm{PL}} \quad \mathrm{NEG} \quad \mathrm{NP}_{15}$-speak-FV $\quad \mathrm{SC}_{2 \mathrm{PL}}$-PRS-speak-FV

'For it is not you who are speaking.'

(New Testament 1923: Matthew 10, 20) 
(69) Kisikongo (south)

Kadi ke yeno nuvova ko.

kadi ke yeno nu- $\emptyset$-vov-a ko

for NEG PRN 2PL SC $2 \mathrm{PL}_{2}$-PRS-speak-FV NEG

'For it is not you who speak.'

(New Testament 1926: Matthew 10, 20)

For the LOC-INF construction, we find the same restriction. In its non-inverted form AUX LOC-INF (70a) it can be properly negated, but it cannot in its inverted form LOC-INF AUX (70b). This incompatibility with negation is corroborated by the fact that in the entire Kikongo corpus no single attestation of such a negative LOC-INF has been found.

(70) Kisikongo (south)

a. Kéna mu zénga nti ko.

ka- $\emptyset$-in-a mu $\emptyset$-zeng-a $\quad$ N-ti ko

NEG.SC ${ }_{1}$-PRS-be-FV $\mathrm{NP}_{18} \quad \mathrm{NP}_{15}$-cut-FV $\quad \mathrm{NP}_{3}$-tree $\mathrm{NEG}$

'He is not cutting a tree.'

b. ${ }^{*}$ Ke mu zenga kena nti ko.

Intended: 'He is not cutting a tree.'

(JDK fieldwork Brussels 2014)

\subsubsection{Argument focus}

Argument focus is not fully compatible with the FIC either. It depends on which term is under the scope of focus and the strategy used. As shown in (68), a FIC may occur in a cleft-construction used to focus a subject. However, argument focus simply involving word order inversion does not seem to be compatible with the FIC, as indicated by the ungrammaticality of the O INF V order in (71c).

(71) Kimanyanga (central)

a. Mbwá ketivónda.

N-bwa ka-eti-vond-a

$\mathrm{NP}_{9}$-dog $\mathrm{SC}_{1}$-PROG-kill-Fv

'He's killing the dog.'

b. Vónda ketivónda mbwá.

$\emptyset$-vond-a ka-eti-vond-a N-bwa

$\mathrm{NP}_{15}$-kill-FV $\mathrm{SC}_{1}$-PROG-kill-FV $\mathrm{NP}_{9}$-dog

'He's killing the dog.' 


\section{c. ${ }^{*}$ Mbwa vonda ketivonda. Intended: 'He's killing the dog.' (JDK fieldwork Brussels 2013)}

To express progressivity, an alternative marker such as -eti- (without a FIC) in (71a) should be used in cases of argument focus involving word order inversion. In the Kisikongo example in (72) the imperfective marker -ang- is used in an argument focus construction. This indicates that the progressive aspect an sich is not incompatible with argument focus. The suffix -ang-is widespread in Bantu and is found with imperfective, habitual, durative and/or iterative meanings (Nurse 2008: 138). Meeussen (1967: 110) has reconstructed it for Proto-Bantu as an imperfective marker. Having originated independently from a PCF marker, it is perfectly combinable with argument focus. It should be noted, however, that most examples are past progressives, which are less explicitly focused compared to present progressives (Güldemann 2003: 350-351). ${ }^{10}$

(72) Kisikongo (south)

Nki bavavanga atantu a Mose?

nki ba-a-vav-ang-a a-tantu a mose

what $\mathrm{SC}_{2}$-PST-Seek-IPFV-FV $\mathrm{NP}_{2}$-enemy conN Moses

'What were Moses' enemies seeking?'

Moyo andi bavavanga.

mu-oyo andi ba-a-vav-ang-a

$\mathrm{NP}_{3}$-Soul POSS 1 SC SC $_{2}$-PST-Seek-IPFV-FV

'They were seeking (to take) his life.'

(JW's Onkanda 2013: 210)

According to Hadermann (1996: 162), there is at least one Kikongo variety in which the combination of a FIC and preverbal argument focus would be

10 We refer the reader to the following paragraph from Güldemann (2003: 349-350): "the synchronic and diachronic links [i.e. between progressive and PCF markers] are only discernable between PRESENTS with predication focus and PRESENT progressives. Other tenses with predication focus do not develop into progressives or recurrently demonstrate a formal similarity with them. This apparent behavioral difference between a present and a non-present progressive is not recoverable from the purely semantic definition of this category. It suggests that progressives in the present have a special discourse behavior not found in other tenses. It is important in this respect that a present progressive relates most directly to an immediate speech situation and is more likely to refer to a state of affairs that is immediately relevant for the particular communicative situation of the interlocutors. Anchored in the deictic viewpoint of the speech participants, a present progressive can focus on the HIC-ET-NUNC of the relevant state of affairs.” 
grammatical, i.e. Kisundi: "Ce stade, où l'objet se trouve antéposé à une forme verbale redoublée, semble être atteint par le suundi”. She gives the example reproduced in (73). However, the presence of the resumptive pronoun dyò in (73b), referring to the object, suggests that we are not dealing with an ordinary SOV structure, but rather with a clause-external object necessitating a more literal translation such as 'The child, the book, he is going to read it', in which both 'the child' and 'the book' are topics.

(73) Kisundi (north)

a. Bùkù ndyèkátá:ngà.

$\emptyset$-buku ndi-eka-tang-a

NP9-book SC $_{1 \text { sG }}$-FuT-read-FV

'I'm going to read the book.'

b. Mwà:nà bùkú kùtá:ngà kèkátá:ngá dyò.

mu-ana Ø-buku ku-tang-a ka-eka-tang-a dyo

$\mathrm{NP}_{1}$-child $\mathrm{NP}_{9}$-book $\mathrm{NP}_{15}$-read-FV SC $_{1}$-FUT-read-FV $\mathrm{PRN}_{9}$

'The child is going to read the book.'

(Hadermann 1996: 162)

A more convincing example is the Kindibu one in (74), in which a focalized locative argument, in this case the inherently focalized question word kweyi 'where', is expressed preverbally before a FIc. It is arguably no coincidence that this combination is attested with the future meaning of the FIC rather than with the progressive. The future is more semanticized than the progressive, which is rather a pragmatic inference of the PCF function of the FIC.

(74) Kindibu (central)

Keti kweyi kwenda kekwenda yandi, muna wau ke tulenda kummona ko?

keti kweyi ku-end-a ke-ø-ku-end-a yandi muna wau

$\mathrm{Q} \quad$ where $\mathrm{NP}_{15}$-go-FV $\quad \mathrm{SC}_{1}$-PRS-NP $\mathrm{N}_{15}$-go-FV $\mathrm{PRN}_{1} \quad \mathrm{DEM}_{18} \quad \mathrm{DEM}_{14}$

ke-tu- $\varnothing$-lend-a ku-N-mon-a ko

NEG-SC ${ }_{1 \mathrm{PL}}$-PRS-Can-FV $\mathrm{NP}_{15}-\mathrm{OC}_{1}$-See-FV NEG

'Where will this person go that we cannot find him?'

(New Testament 1923: John 7, 35)

In the entire Kikongo corpus, no other attestations have been found of the co-existence of preverbal argument focus and a FIC or a LOC-INF construction within the same clause. The following elicited examples show that the noninverted AUX LOC-INF construction can be combined with a preverbal object (75a), but the inverted LOC-INF AUX construction cannot (75b). 
(75) Kisikongo (south)

a. Nti kéna mu zénga.

Ni-ti ka- $\emptyset$-in-a mu $\emptyset$-zeng-a

$\mathrm{NP}_{3}$-tree $\mathrm{SC}_{1}$-PRs-be-FV $\mathrm{NP}_{18} \quad \mathrm{NP}_{15}$-Cut-Fv

'He's cutting the tree.'

b. *Nti mu zenga kena. / ${ }^{*}$ Mu zenga nti kena.

Intended: 'He's cutting the tree.'

(JDK fieldwork Brussels 2014)

\subsection{Distribution in the conjugational system}

Another argument used by Güldemann (2003: 344) to claim a historical evolution from focus to progressive marking is that "the marking devices regularly have a wider distribution in the focus domain than in the domain of time marking to which the progressive belongs". This is the case for the FIc. While it occurs both as a PCF marker and as a progressive marker in the present tense; in the past tense it can only have a PCF reading, as illustrated by the Kimanyanga examples in (76), where the FIC marks a contrastive focus on the state of affairs in the past tense.

(76) Kimanyanga (central)

a. Bwé, waténgí vó yandí wavondelwé? bwe u-a-tang-idi vo yandi u-a-vond-u-idi e Q $\quad \mathrm{SC}_{2 \mathrm{SG}}$-PST-read-PRF and $\mathrm{PRN}_{1} \quad \mathrm{SC}_{1}$-PST-kill-PASS-PRF Q 'Did you read that he was killed?'

b. Nkhátu, wá yawílu wo.

$\begin{array}{llll}\text { nkatu } & \emptyset \text {-u-a } & \text { i-a-u-idi } & \text { wo } \\ \text { no } \quad \mathrm{NP}_{15} \text {-hear-Fv } & \text { SC }_{1 \mathrm{sG}} \text {-PST-hear-PRF } & \text { PRN }_{14} \\ \text { 'No, I heard it.' } & & \end{array}$

(JDK fieldwork Brussels 2013)

In (77), the past progressive is expressed by means of the pre-final -ang-, while the FIC again conveys a contrastive focus on the state of affairs.

(77) Kimanyanga (central)

a. Bwé, tánga lukéji tángánga minístre bukakótelengé?

bwe $\varnothing$-tang-a lu-kezi-tang-ang-a ministre bu-ka- $\varnothing$-kot-idingi e Q $\quad \mathrm{NP}_{15}$-read-FV $\mathrm{SC}_{2 \mathrm{PL}}$-PST-read-IPFV-Fv minister $\mathrm{PP}_{14}$-SC $\mathrm{SC}_{1}$-PROX-enter-PFV $\mathrm{Q}$ 'Were you reading when the minister entered (the room)?' 
b. Nkhátu, lambá tukezilambánga.

nkatu Ø-lamb-a tu-kezi-lamb-ang-a

no $\quad \mathrm{NP}_{15}$-sleep-FV $\quad \mathrm{SC}_{1 \mathrm{PL}}$-PST-Sleep-IPFV-FV

'No, we were sleeping.'

(JDK fieldwork Brussels 2013)

This argument does not hold, however, with regard to the LOC-INF construction. As a primary progressive marker it is compatible with both present and past tense. This is illustrated in (5) and (45) for the present, and in (4), (48), (49) and (50) for the past.

\subsection{Geographical distribution}

Finally we examine whether the geographical distribution of the different functions of both constructions manifesting polysemy between PCF and progressivity corroborates the assumed directionality of evolution, as Güldemann (2003: 344) proposes for similar polysemic markers.

Regarding the FIC its use as a PCF marker is clearly more widespread than its use as a progressive marker across the KLC. Its use as a PCF marker has been attested in all phylogenetic Kikongo subgroups and should thus be reconstructed for Proto-Kikongo. However, its use as a progressive marker is only unmistakably attested in the South, West and Central subgroups. Straightforward evidence is missing for the North and East subgroups. Two possible scenarios are conceivable: 1) The progressive function of the FIC goes back to Proto-Kikongo, but fell into disuse in several languages because of competition with more regional (and thus more recent) progressive markers; 2) The progressive aspect only developed at a later stage, after the fragmentation of the most recent common ancestor of the current-day Kikongo varieties, either at some intermediate ancestral node or independently within the different subgroups. It is difficult to tell which of the two scenarios is the most plausible, due to the fact that progressivity is so intimately and inherently linked with predication focus. We argue, however, that it actually rather turns up as a secondary reading of its more central PCF use than as a truly independent meaning. As we know, marginal readings of more central instantiations tend to pop up and disappear occasionally and recurrently, a phenomenon known as 'semantic polygenesis' (Geeraerts 1997: 62). Hence, it is not excluded that progressivity as a less central instantiation of the FIc had already cropped up in, for instance, Proto-Kikongo, but then fell into disuse in certain subgroups due to the prominence of more recently developed dedicated progressive markers. On the other hand, the FIC may also have developed its progressive 
reading as an independent innovation and through convergent evolution in different Kikongo subgroups. This certainly seems to be the case for the development of its future meaning, which is an innovation confined to the southern and south-eastern part of the KLC.

With regard to the LOC-INF construction the situation is exactly the opposite. Its use as a progressive marker is clearly more widespread, occurring in all of the Kikongo subgroups, and thus suggesting a Proto-Kikongo status. Its use as a PCF marker, on the other hand, has only been attested in the East subgroup, which from a purely geographical view points towards a more recent innovation.

The geographical distributions of the functions of the FIC and the LOC-INF constructions are represented on Map 1 and Map 2 respectively in Addendum D.

\subsection{Summary}

Table 1 compares the features of the FIC and the LOC-INF constructions.

Table 1: Comparative features of the fronted-infinitive construction (FIC) and the locative-infinitive construction (LOC-INF).

\begin{tabular}{llll}
\hline & FIC & AUX LOC-INF & LOC-INF AUX \\
\hline Inverted word order & $\checkmark$ & $x$ & $\checkmark$ \\
Morphological inversion marking & $\checkmark$ & $x$ & $\checkmark$ \\
Compatible with negation & $x$ & $\checkmark$ & $x$ \\
Compatible with preverbal argument focus & $x$ & $\checkmark$ & $x$ \\
Most widely distributed function in conjugational system & PCF & PROG (no PCF) & PROG \\
Most widely distributed function geographically & PCF & PROG (no PCF) & PROG \\
\hline
\end{tabular}

The properties of the FIC point towards an evolution from focus marker towards progressive marker. Both geographically and in the conjugation system its function as a PCF marker is more widespread than its function as a progressive marker. Moreover, its syntactic and pragmatic behaviour regarding word order, morphological marking and its incompatibility with other focus constructions clearly shows an underlying focus construction. This directionality of evolution fits into wider cross-linguistic evidence and ties in with the claim that "a change [in terms of grammaticalization] frequently starts in the domain of pragmatics [e.g. PCF] and goes in the direction of, or even ends in, the domain of semantics [e.g. progressive aspect]" (Güldemann 2003: 351). Progressive markers clearly straddle the functional domains of semantics (aspect) and pragmatics (inherent focality). Verb reduplication, the most salient formal feature of the FIc, has an iconic value also pertaining to both functional domains. On the one hand, it puts 
emphasis on the event expressed by the verb by doubling it, which is the primary function of PCF. On the other hand, it may highlight the iterative or intensive character of the action, closely linked with progressive aspect and ongoing, continuous actions. As shown in (78) other types of verb reduplication serve to express iterative or intensive action in Kikongo (Bentley 1887: 974; Laman 1912: 178).

(78) Kisikongo (south) tunga-tunga

$\emptyset$-tung-a Ø-tung-a

$\mathrm{NP}_{15}$-build-FV $\mathrm{NP}_{15}$-build-FV

'to build quickly'

(Bentley 1887: 974)

The future function is clearly the most recent innovation of the FIc, given its restricted geographical distribution. It may have evolved out of its use as a progressive marker, since future tense and progressive aspect (traditionally) pertain to the same functional domain, i.e. that of semantics (rather than pragmatics). Whereas a progressive refers to an action already started but not yet finished, a future refers to an action not yet started and not yet finished. They thus both share the semantic characteristic that the action described by the verb has not finished as yet. Analogous shifts from present/progressive markers to future markers have been observed both inside and outside the Kikongo area. In South Kikongo, for instance, the general present marked by a $\emptyset$-tense prefix and the final vowel - $a$ evolved into a future marker (Dom and Bostoen 2015). The marker -eka- is used in Kiyombe to express progressivity and in Kisundi to express the future, as one can observe when comparing (79) below with (73) above. One would expect the progressive to evolve into the near future first, but this intermediate step is not clearly attested for the FIC within Kikongo. We do observe it, however, for the Loc-INF construction.

(79) Kiyombe (west)

Ndieka-sumba.

ndi-eka-sumb-a

$\mathrm{SC}_{1 \mathrm{SG}}$-PROG-buy-FV

'I'm buying.'

(Bittremieux 1923-1927: 839)

The LOC-INF construction also displays some features of an underlying focus function, such as word order, morphological marking and the incompatibility 
with marked contexts such as negation or argument focus. However, its distribution - both geographically and in the conjugational system - does not corroborate a claim for an original PCF function. Geographically speaking it is rather the other way around. Its progressive function is distributed over all of the Kikongo subgroups, while its PCF function only occurs in one, i.e. East Kikongo. Two scenarios are possible: (1) the Loc-INF construction originally had a progressive function and evolved in a few languages to a PCF marker; (2) it originally had a PCF function which evolved in the whole KLC to a progressive marker, gradually losing its function as PCF marker due to competition with other PCF markers such as the FIC and kwandi, and only surviving as a PCF marker in the East subgroup. This second scenario implies that the LOC-INF construction as PCF marker is relatively old, preceding its function as progressive marker, which should be ascribed to Proto-Kikongo. This second scenario is not only the less economic, it is also at odds with the etymology of the Loc-INF construction. Crosslinguistically, locatives are an important source for the development of progressive markers (Bybee and Dahl 1989: 79; Bybee et al. 1994: 135; Güldemann 2003: 346). It is therefore more reasonable to assume that the LoC-INF construction was basically a progressive marker and that it only became subsequently involved in the expression of PCF. This is a functional extension from the domain of semantics to the domain of pragmatics, which is less common than the other way around, but can be accounted for by the inherently focused and eventcentral nature of the progressive. Moreover, certain of the focus strategy features of the LOC-INF construction, such as inverted word order and the use of the $k a$ prefix, are only observed when the most salient component of the construction, i.e. LOC-INF, precedes the Aux. Although no pragmatic difference is observable between AUX LOC-INF and LOC-INF AUX in present-day Kikongo, and although the former is significantly less frequent, this probably was not always the case. The original word order AUX LOC-INF most likely just started out as an unmarked progressive marker, while its inversion might have had a focus-related function. This inversion is nowadays losing (or has lost) its pragmatic markedness, which might have happened analogously with the pragmatic neutralization of SVO > SOV in some cases, or with locative inversions without a marked focus function, as in (80) and (81):

(80) Cizali (west)

Mu cikúúku kakééle, lámba kilámba.

mu ci-kuuku ka- Ø-kal-idi Ø-lamb-a ka-i-lamb-a

$\mathrm{NP}_{18} \quad \mathrm{NP}_{7}$-kitchen $\mathrm{SC}_{1}$-PRS-be-PRF $\mathrm{NP}_{15}$-cook-FV SC ${ }_{1}$-PRS-cook-FV

'She's in the kitchen, she's cooking.'

(KongoKing fieldwork 2012) 
(81) Kisolongo (south)

Ku nzo bena.

$\mathrm{ku} \quad \mathrm{N}-\mathrm{zo}$ ba- $\varnothing$-in-a

$\mathrm{NP}_{17} \quad \mathrm{NP}_{9}$-house $\mathrm{SC}_{2}$-PRs-be-FV

'They are in the house.'

(JDK fieldwork Courselles 2013)

\section{Conclusions}

In this article we have provided a detailed descriptive and comparative account of two polysemous and partly synonymous constructions in Kikongo, i.e. the FIC and the locative-infinitive construction (LOC-INF). In different Kikongo varieties, both periphrases are involved in the expression of predication focus, progressive aspect and/or - to a lesser degree - future tense. In adopting these different functions both constructions straddle pragmatics and semantics, but they clearly do not have their origins in the same functional domain.

We have shown that the FIC is primarily a PCF construction that still persistently exhibits all features of an underlying focus construction, even if it expresses aspect or tense. As illustrated in Figure 1, it is first and foremost an information-packaging device, but through pragmatic inference it developed aspect- and tense-related semantics, which are often difficult to conceive as truly independent meanings from the PCF meaning. Especially the progressive reading most often emerges as a secondary reading of PCF, although it also has been observed outside typical focus

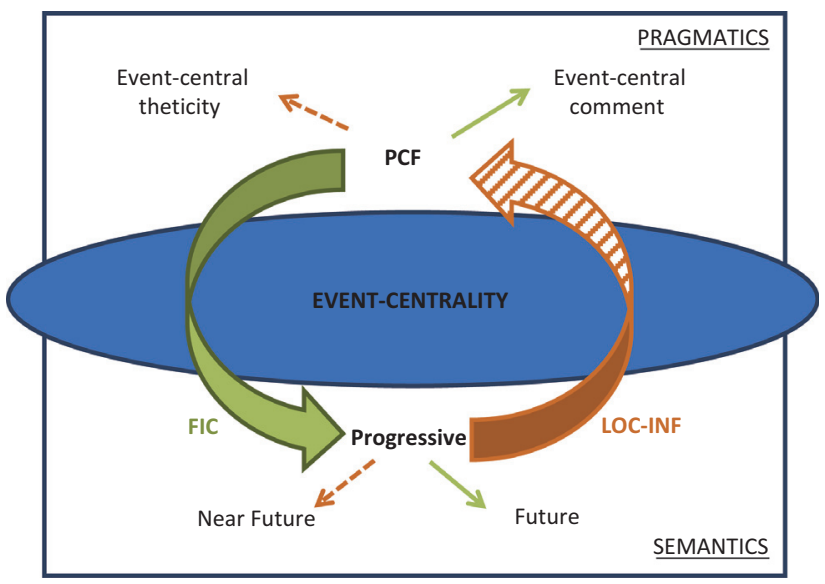

Figure 1: Functional evolution of the fronted-infinitive (solid) and locative-infinitive (dashed) constructions in the pragmatics-semantics interface. 
contexts. The future meaning, which the FIC conveys in the southern part of the KLC, is by no means bound to the construction's primary PCF function and must have semanticized from its progressive reading, the semantic shift from present (progressive) to (near) future being common in the world's languages.

The LOC-INF construction underwent a reverse development, as shown in Figure 1. It started out as a grammatical marker of progressivity and entered the functional domain of pragmatics - at least in East Kikongo - by becoming involved in the expression of PCF. The (near) future meaning it displays in certain Kikongo varieties is rather an independent development. Being only a secondary PCF marker, it does not manifest as persistently as the FIC all typical features of an underlying focus construction. Those features which it does share with the FIC, such as the preverbal position of the focused element and morphological marking in the verb's subject concord paradigm, are optional in that they only occur in the construction's LOC-INF AUX variant. As opposed to its non-inverted counterpart AUX LOC-INF, LOC-INF AUX was originally probably more marked and specifically linked with focus, but this is no longer observable in present-day Kikongo data. We suggest that it went through a process of pragmatic bleaching analogous with other inversion structures, such as SOV and LOC V orders, which also no longer systematically mark argument focus.

To account for the different focus-related uses of the FIC, i.e. not only PCF in the strict sense of Güldemann (2003) but also thetic and categorical statements in which the verb is the central piece of information, we have introduced the notion of eventcentrality. The FIC is used or can be used whenever the most salient information of a statement is centred around the event expressed by the verb. As summarized in Figure 1 this prototypical notion of event-centrality also accounts for the extension of the FIc's functional domain to progressivity, or the other way around for the broadening of the LOC-INF construction's scope from progressivity to PCF. Since the ongoing nature of the event described by the verb is the most important information conveyed by a progressive verb, it is an inherently focused verb category, which naturally constitutes the focus domain of an utterance. To conclude, event-centrality can be considered here as the embodiment of the pragmatics-semantics interface where the common Kikongo constructions FIC and LOC-INF meet through their shared PCF and progressivity functions. In this article these intricate near-symmetrical relationships were substantiated by ample evidence from a large number of varieties from the KLC, arguably a first in Bantu-language studies.

Acknowledgements: Earlier versions of this article were presented at the SLE 2013 conference and a workshop on Information Structure organized by Tom Güldemann, Ines Fiedler and Yukiko Morimoto in Berlin, in December 2013. Thanks are due to the participants in these meetings, and we are grateful to Doris Payne for detailed comments on an earlier draft. 
Funding: The $\mathrm{PhD}$ research of the first two authors is funded through an FWO fellowship. The research of the last two authors is funded by the European Research Council through a Starting Grant (KongoKing, Grant No. 284126) and by the Special Research Fund of Ghent University.

\section{References}

Anonymous. 1926. Luwawanu Luampa. London: The British and Foreign Bible Society.

Anonymous. 1929. Luwawanu Luamona. London: The British and Foreign Bible Society.

António, Diogo. n.d. Provérbios em Kikongo. Verona: Tipolitografia don Calabria.

Baka, Jean. 1992. Essai de description du tso:tso, parler ko:ngo du Nord de l'Angola. Brussels: Université libre de Bruxelles, mémoire de DEA.

Baptist Missionary Society. 1916. Luwawanu Luankulu, Nkanda mia lusansu. London: Bible Translation Society.

Bastin, Yvonne. 1989. El prefijo locativo de la clase 18 y la expresión del progresivo presente en Bantu. Estudios africanos 4. 35-55, 61-86.

Bearth, Thomas. 2003. Syntax. In Derek Nurse \& Gérard Philippson (eds.), The Bantu Languages, 121-142. London: Routledge.

Bentley, William Holman. 1887. Dictionary and Grammar of the Kongo Language as Spoken at San Salvador, the Ancient Capital of the Old Kongo Empire, West Africa. London: Baptist Missionary Society and Trübner \& Co.

Bittremieux, Léo. 1923-1927. Mayombsch idioticon. Gent: Erasmus.

Bontinck, François \& Damase Ndembe Nsasi. 1978. Le catéchisme kikongo de 1624. Ré-édition critique. Brussels: Académie royale des sciences d'outre-mer.

Bostoen, Koen \& Gilles-Maurice de Schryver. 2015. Linguistic innovation, political centralization and economic integration in the Kongo kingdom: Reconstructing the spread of prefix reduction. Diachronica 32. 139-185.

Bostoen, Koen \& Léon Mundeke. 2012. Subject marking and focus in Mbuun (Bantu, B87). Southern African Linguistics and Applied Language Studies 30. 139-154.

Bouka, Léonce Yembi. 1989. Eléments de description du kaamba, parler bantou de la République Populaire du Congo (Groupe Koongo, H17b). Brussels: Université libre de Bruxelles, mémoire de licence spéciale.

Bowern, Claire. 2008. Linguistic Fieldwork. New York: Palgrave Macmillan.

Bybee, Joan L. \& Östen Dahl. 1989. The creation of tense and aspect systems in the languages of the world. Studies in Language 13. 51-103.

Bybee, Joan L., Revere D. Perkins \& William Pagliuca. 1994. The Evolution of Grammar. Tense, aspect, and modality in the languages of the world. Chicago: University of Chicago Press.

Cardoso, Mattheus. 1624. Dovtrina Christaã [sic]. Composta pelo P. Marcos lorge da Companhia de IESV Doutor em Theologia. Acrescent ada pelo Padre Ignacio Martinz da mesma Companhia Doutor Theologo. De nouo traduzida na lingoa do Reyno de Congo, por ordem do P. Mattheus Cardoso Theologo, da Campanhia de IESV. Lisbon: Geraldo da Vinha.

Coene, Alfonse. 1960. Kikongo: Notions grammaticales. Vocabulaire français-kikongo, néerlandais-latin. Tumba: Imprimerie Maison Catholique.

Cuénot, F. 1776. Essai d'une grammaire Congo suivant l'accent de Kakongo. Besançon Municipal Library, manuscript no. 523. 
Cysouw, Michael \& Jeff Good. 2013. Languoid, doculect, glossonym: Formalizing the notion 'language'. Language Documentation \& Conservation 7. 331-359.

De Cleene, Natalis \& Louis De Clercq. 1920. Evanzeli Isantu. I Pfumu Etu Yezu Kristo ayi Mambu ma Bapostolo. Turnhout: H. Proost.

De Clercq, Louis. 1921. Grammaire du kiyombe. Brussels: Goemare.

De Kind, Jasper. 2014. Pre-verbal focus in Kisikongo (H16a, Bantu). ZAS Papers in Linguistics 57. 95-122.

de Schryver, Gilles-Maurice, Rebecca Grollemund, Simon Branford \& Koen Bostoen. forthc. 2015. Introducing a state-of-the-art phylogenetic classification of the Kikongo language cluster. Africana Linguistica 21.

Dik, Simon C. 1997. The Theory of Functional Grammar, Part 1: The structure of the clause. Berlin: Mouton de Gruyter.

Dom, Sebastian \& Koen Bostoen. forthc. 2015. Examining variation in the expression of tense/ aspect to classify the Kikongo language cluster. Africana Linguistica 21.

Evans, Nicolas. 2003. Context, culture, and structuration in the languages of Australia. Annual Review of Anthropology 32. 13-40.

Geeraerts, Dirk. 1997. Diachronic Prototype Semantics. A Contribution to Historical Lexicology. Oxford: Oxford University Press.

Gottschligg, Peter. 1992. Durative Prädikate und Verbsemantik im Ful. In Erwin Ebermann, Erich R. Sommerauer \& Karl É. Thomanek (eds.), Komparative Afrikanistik, 151-169. Wien: Institut für Afrikanistik.

Grégoire, Claire. 1975. Les locatifs en bantu. Tervuren: Musée royal de l'Afrique centrale.

Güldemann, Tom. 2003. Present progressive vis-à-vis predication focus in Bantu. A verbal category between semantics and pragmatics. Studies in Language 27. 323-360.

Güldemann, Tom. 2010. Preposed verb doubling and predicate-centered focus. Paper presented at the international conference of the SFB 632 "Information Structure", Potsdam University.

Guthrie, Malcolm. 1971. Comparative Bantu: An Introduction to the Comparative Linguistics and Prehistory of the Bantu languages. Volume 2: Bantu Prehistory, Inventory and Indexes. London: Gregg International.

Hadermann, Pascale. 1996. Grammaticalisation de la structure 'infinitif + verbe conjugué' dans quelques langues bantoues. Studies in African Linguistics 25. 155-196.

Hopper, Paul J. 1991. On some principles of grammaticalization. In Elizabeth Closs Traugott \& Bernd Heine (eds.), Approaches to Grammaticalization, 17-35. Amsterdam: Benjamins.

Horn, Laurence R. 1989. A Natural History of Negation. Chicago: Chicago University Press. Hyman, Larry \& John Robert Watters. 1984. Auxiliary focus. Studies in African Linguistics 15. 233-273. Kiefer, Ferenc. 1994. Some peculiarities of the aspectual system in Hungarian. In Carl Bache, Hans Basbøll \& Carl-Erik Lindberg (eds.), Tense, Aspect and Action. Empirical and Theoretical Contributions to Language Typology, 185-205. Berlin: Mouton de Gruyter.

Kiss, Katalin É. 1998. Identificational focus versus information focus. Language 74. 245-273. Laman, Karl Edward. 1912. Grammar of the Kongo Language (Kikongo). New York: Christian Alliance Publishers.

Lambrecht, Knud. 1994. Information Structure and Sentence Form. Cambridge: Cambridge University Press.

Le Ussel, P. 1888. Petite grammaire de la langue Fiote: dialecte du Loango. Loango: Imprimerie de la Mission.

MacGaffey, Wyatt. 2000. Kongo Political Culture. The Conceptual Challenge of the Particular. Bloomington: Indiana University Press. 
Marchal-Nasse, Colette. 1989. De la phonologie à la morphologie du nzebi, langue bantoue

(B52) du Gabon. Brussels: Université libre de Bruxelles, PhD dissertation.

Matuka, Yeno Mansoni. 1991. The Pragmatics of Palavering in Kikoongo. Muncie: Ball State University, PhD dissertation.

Mbambu, Ignace. 1956. Nsangu Zimbote zi Santa Luka. Kisantu: Imprimerie St. Ignace.

Meeussen, Achille Emiel. 1967. Bantu Grammatical Reconstructions. Africana Linguistica 3. 79-121. Mingas, Amélia Arleta. 1994. Étude grammaticale de l'iwoyo (Angola). Paris: Université René

Descartes - Paris 5, PhD dissertation.

Morimoto, Yukiko. 2014. Focus marking in Kikuyu (E51). Paper presented at the International

Workshop on Bantu Languages, SOAS, University of London.

Mpanzu, Luzayamo. 1994. Eléments de description du zombo, parler kongo H16k d'Angola.

Brussels: Université libre de Bruxelles, mémoire de licence spéciale.

Ndouli, Guy. 2012. Focalisation et ordre des mots en kikongo véhiculaire (H10A) de Pointe-Noire et en civili (H12). Paper presented at the 42nd Colloquium of African Languages and Linguistics, Leiden University.

N’landu Kitambika. 1994. Eléments de description du kisuundi (H13b), parler de la République du Congo. Brussels: Université libre de Bruxelles, mémoire de licence spéciale.

Nurse, Derek. 2008. Tense and Aspect in Bantu. Oxford: Oxford University Press.

Sasse, Hans-Jürgen. 1987. The thetic/categorical distinction revisited. Linguistics 25. 511-580.

Sasse, Hans-Jürgen. 1996. Theticity (Arbeitspapiere, Neue Folge 27). Cologne: Institut für Sprachenwissenschaft, Universität zu Köln.

Schadeberg, Thilo C. 2003. Historical Linguistics. In Derek Nurse \& Gérard Philippson (eds.), The Bantu Languages, 143-163. London: Routledge.

Skopeteas, Stavros, Ines Fiedler, Sam Hellmuth, Anne Schwarz, Ruben Stoel, Gisbert Fanselow, Caroline Féry \& Manfred Krifka. 2006. Questionnaire on Information Structure (QUIS): Reference Manual (ISIS | Working Papers of the SFB 632 "Information Structure"). Potsdam: Universitätsverlag Potsdam.

Van Den Eynde, Karel. 1968. Éléments de grammaire yaka: phonologie et morphologie flexionnelle. Kinshasa: Université Lovanium, Publications Universitaires.

Van Valin, Robert D. \& Randy J. LaPolla. 1997. Syntax: Structure, Meaning and Function. Cambridge: Cambridge University Press.

Vuylsteke, Pierre. 1923. Evangelia Ziya. Nsangu za Yezo-Kristo ye za Ntumwa Zandi. Tumba: Mission catholique.

\section{Addendum A: Sources for the Kikongo data}

\section{Notes on the fieldwork data}

- Data labelled as "KongoKing Fieldwork 2012" were collected by the four authors of the present article during a joint fieldwork trip undertaken in the Lower Congo Province of the DRC in August-September 2012, which aimed at the documentation of lesser-known Kikongo varieties, namely Kimbata, Kimpangu, Kimbeko and Kinkanu (East), Kisolongo (South), and Ciwoyo, Cizali, Cimbala, Cilinji and Kizobe (West), using questionnaires dedicated to 
sound changes, vocabulary, tense/aspect marking and Information Structure, and through the recording of stories and spontaneous speech.

- Data labelled as "JDK fieldwork Brussels 2013", "JDK fieldwork Courselles 2013", “JDK fieldwork Antwerp 2013” and "JDK fieldwork Brussels 2014" were collected by the first author in September 2013, November 2013 (2 x) and March 2014, with native speakers of respectively Kimanyanga (Central), Kisolongo (South) and (2 x) Kisikongo (South) through elicitation dedicated to the constructions studied in this article. We wish to thank Bernard Ntoto (Kimanyanga), Francisco Simão (Kisolongo), Berizon Gomes (Kisikongo) and Manuel André (Kisikongo) for their time and patience.

- Data labelled as "IB fieldwork Mbanza Kongo 2003" were collected and transcribed by Inge Brinkman during her fieldwork in Mbanza Kongo in November 2003, as part of the research project 'Nationalism in Angola: the culture of politics', funded by the FWO (Belgium). We wish to thank her for the permission to use her Kisikongo data, for which her consultant was Antonio Risposta Andre.

\section{Sources per Kikongo variety, ordered per sub-group and chronologically}

\section{SOUTH}

\section{South Kikongo}

- Cardoso 1624 (as edited by Bontinck and Ndembe Nsasi 1978).

- António n.d. [twentieth century].

\section{Kisikongo}

- Bentley 1887.

- $\quad$ Old Testament 1916 = Baptist Missionary Society 1916.

- $\quad$ New Testament 1926 = Anonymous 1926.

- $\quad$ IB fieldwork Mbanza Kongo 2003.

- JW's ... 2013 = Data from the website of the Jehovah's Witnesses: http:// www.jw.org/kwy/.

- JDK fieldwork Antwerp 2013.

- $\quad$ JDK fieldwork Brussels 2014.

\section{Kitsotso}

- Baka 1992.

\section{Kizombo}

- Mpanzu 1994. 


\section{Kisolongo}

- $\quad$ KongoKing fieldwork 2012.

- $\quad$ JDK fieldwork Courselles 2013.

\section{WEST}

\section{Kakongo}

- Cuénot 1776.

\section{Civili}

- $\quad$ Le Ussel 1888.

- $\quad$ Ndouli 2012.

\section{Kiyombe}

- $\quad$ New Testament $1920=$ De Cleene and De Clercq 1920.

- $\quad$ Bittremieux 1923-1927.

\section{Iwoyo}

- Mingas 1994.

\section{Ciwoyo}

- $\quad$ KongoKing fieldwork 2012.

\section{Cizali}

- $\quad$ KongoKing fieldwork 2012.

\section{CENTRAL}

\section{Kimanyanga}

- $\quad$ ms. Laman c. 1915, in MacGaffey 2000.

The Kikongo texts which MacGaffey published in his book were extracts from a total of 10,000 manuscript pages in Kikongo, collected by the Swedish missionary Karl Edward Laman. Written by native Kikongo speakers, they constitute responses to questionnaires that dealt with every aspect of Kongo culture, most of them filled in by Laman's own closest associates at the mission stations of Kinkenge, Kingoyi, Nganda, Mukimbungu, Diadia, Lolo, and Musana. The original Kikongo manuscript pages have been microfilmed and are available in that form from the National Archives in Stockholm (MacGaffey 2000: x, 36-37).

- Matuka 1991.

- $\quad$ JDK fieldwork Brussels 2013. 


\section{Kindibu}

- $\quad$ New Testament 1923 = Vuylsteke 1923.

\section{"Fiote" (also known as Bwende)}

- $\quad$ New Testament 1929 = Anonymous 1929.

\section{EAST}

\section{Kintandu}

- $\quad$ New Testament 1956 = Mbambu 1956.

\section{Kimbeko}

- $\quad$ KongoKing fieldwork 2012.

\section{NORTH}

\section{Kikamba}

- Bouka 1989.

\section{Kisundi}

- N’landu Kitambika 1994.

- Hadermann 1996.

\section{Addendum B: List of abbreviations}

$\begin{array}{ll}\emptyset & \text { zero affix } \\ \text { APPL } & \text { applicative } \\ \text { AUGx } & \text { augment of class } x \\ \text { AUX } & \text { auxiliary } \\ \text { CONNx } & \text { connective of class } x \\ \text { DEMx } & \text { demonstrative of class } x \\ \text { DIST } & \text { distal } \\ \text { EXPL } & \text { expletive } \\ \text { FIC } & \text { fronted-infinitive construction } \\ \text { FM } & \text { focus marker } \\ \text { FUT } & \text { future } \\ \text { FV } & \text { final vowel } \\ \text { IMP } & \text { imperative } \\ \text { INF } & \text { infinitive } \\ \text { IPFV } & \text { imperfective marker } \\ \text { LOC } & \text { locative } \\ \text { N } & \text { homorganic non-syllabic nasal } \\ \text { N } & \text { homorganic syllabic nasal }\end{array}$




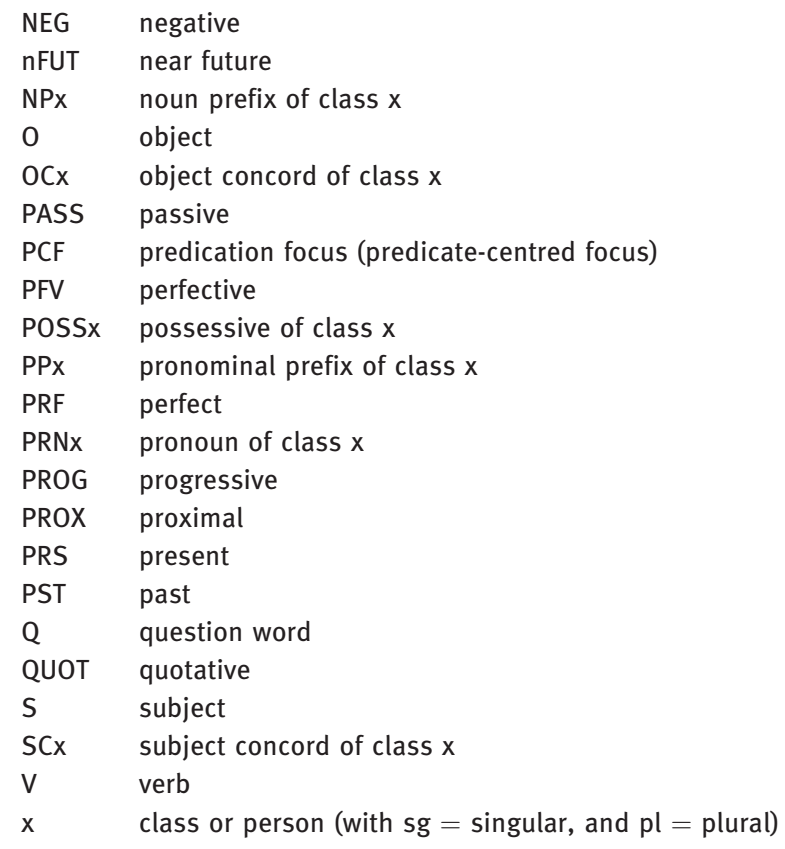

\section{Addendum C: Terminology table}

Assertive focus (New information focus)

Contrastive focus

(Identification focus)

Predicate focus

Predication focus

(Predicate-centred focus, PCF)

Argument focus

(Term focus)

Truth (value) focus
Highlighting pragmatic information which the speaker wishes to add to the hearer's knowledge

Replacing pragmatic information in the hearer's mind

Focus targeting the whole verb phrase including the object and/or adjunct

Focus centred on the predicate, but excluding objects and adjuncts. Centres either on the verb lexeme or on a predication operator linked with the verb expressing values such as polarity, truth, time, aspect, or modality

Focus targeting specific nominal and adverbial clause constituents

Focus pertaining to the clause's positive truth value, as opposed to its negated counterpart

Focus on the lexical meaning of the verb 


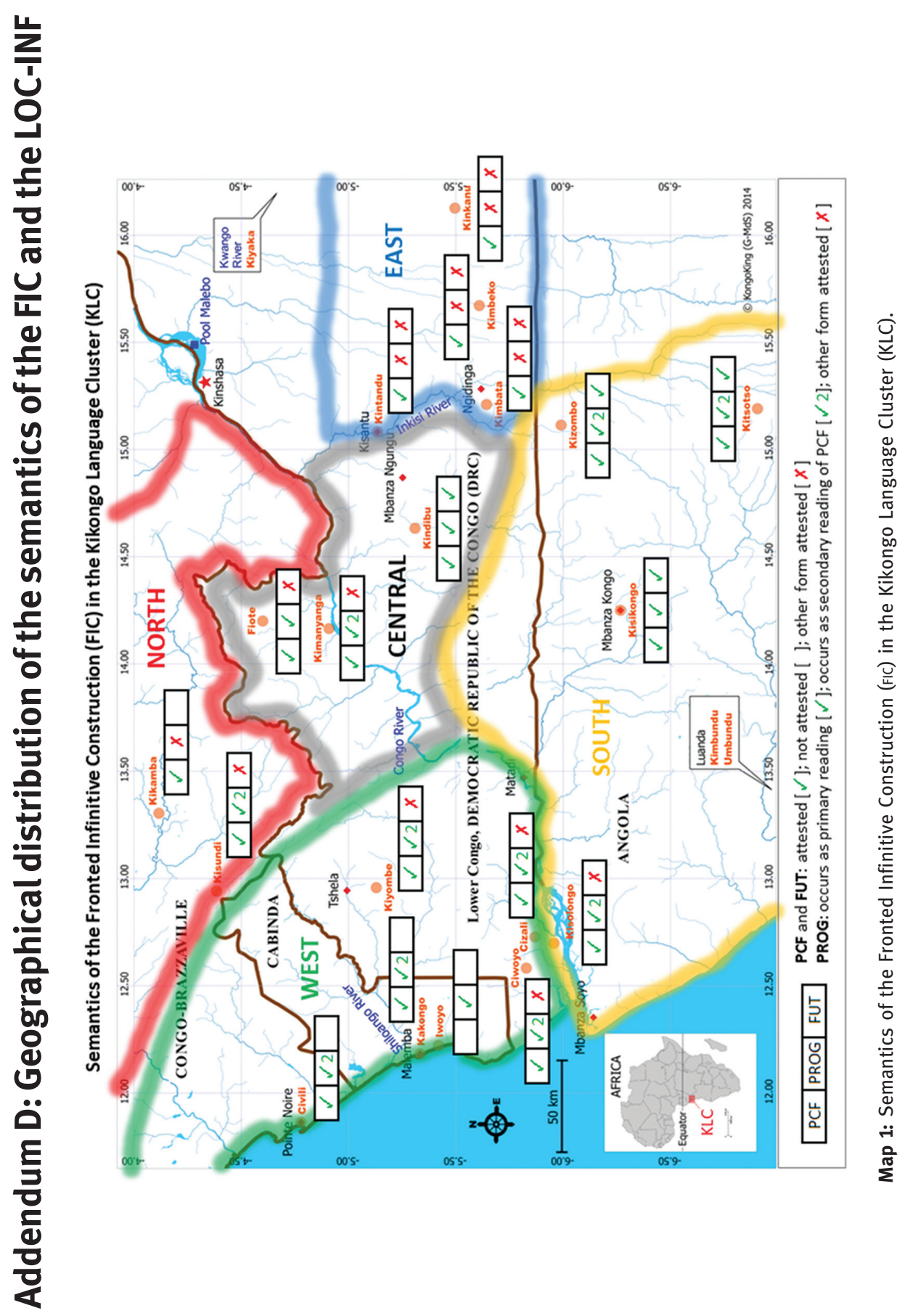




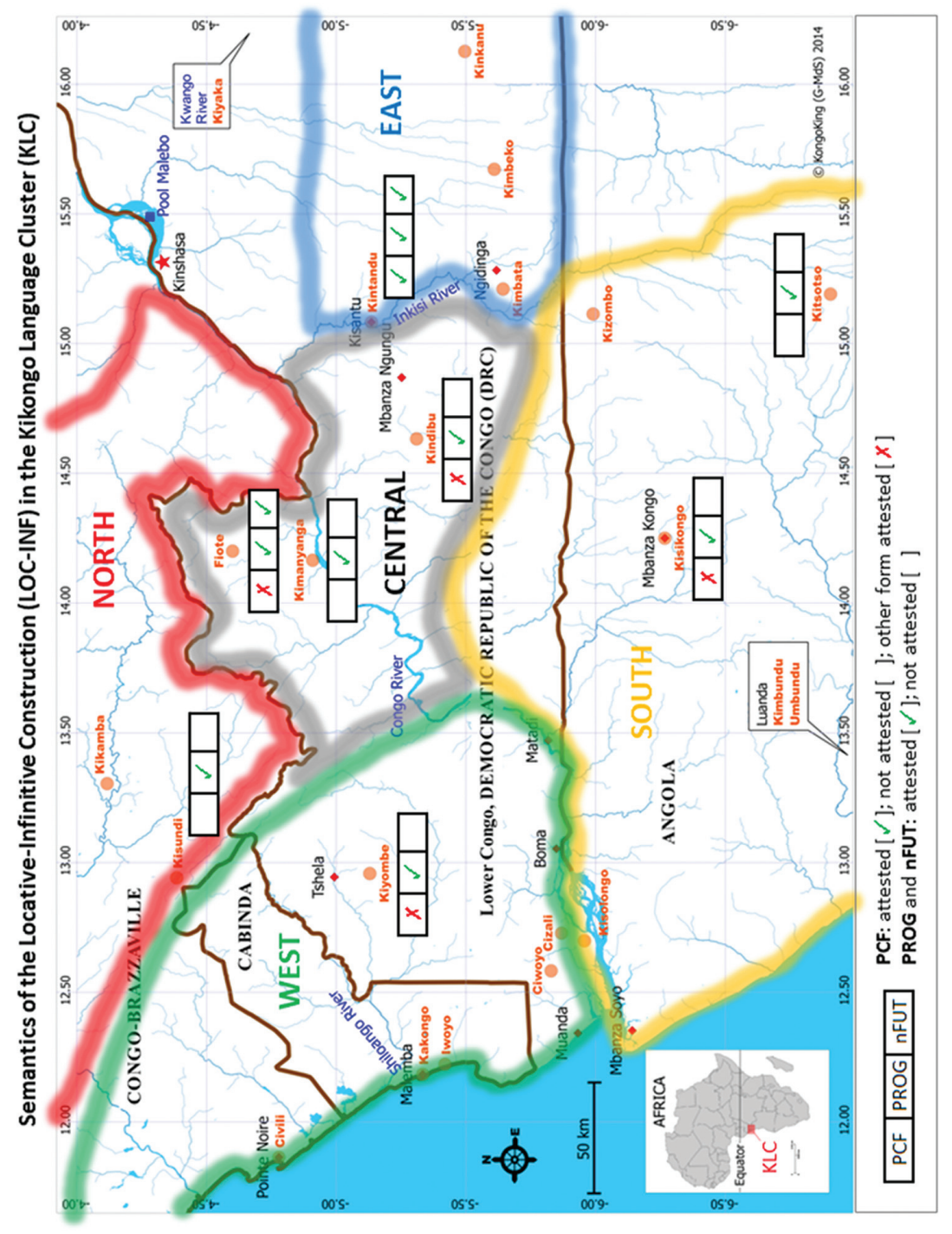

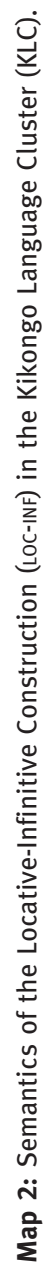

